\title{
POSSE, UM FATO E UM DIREITO: UMA ANALOGIA A LUZ DO CRIACIONISMO
}

\section{ARTIGO ORIGINAL}

SOUZA, Paulo Felix de ${ }^{1}$

VIANA, Joseval Martins ${ }^{2}$

SOUZA, Paulo Felix de. VIANA, Joseval Martins. Posse, um fato e um direito: Uma analogia a luz do criacionismo. Revista Científica Multidisciplinar Núcleo do Conhecimento. Ano 05, Ed. 10, Vol. 23, pp. 122-167. Outubro de 2020. ISSN: 24480959, Link de acesso: https://www.nucleodoconhecimento.com.br/lei/luz-docriacionismo

\section{RESUMO}

Este artigo teve como pretensão trazer uma abordagem nos termos do Direito de Propriedade e seus reflexos diretos e indiretos no exercício pleno de domínio. Sabendo-se que não há propriedade sem posse e nem posse sem propriedade, neste contexto foi verificado que o direito de propriedade e o direito de posse são autônomos entre si, recebendo tratamento diferenciado devido a sua elasticidade ou abrangência na qual implica em outros ramos do direito. Sendo estes os objetivos gerais e nessa esteira foi aventada a seguinte possibilidade em relação ao objetivo específico: As Leis teriam sido inspiradas a Luz do Criacionismo? Quais os danos advindos da (Lei, n $14.223 / 2006)$ em relação ao direito de propriedade e de posse? Diante da hipótese, este artigo se tornou relevante pelo conteúdo histórico Judaico-Cristão, respeitandose o livre arbítrio do Espírito de cada ser humano. Assim a pesquisa caracteriza-se

\footnotetext{
${ }^{1}$ Acadêmico de Direito pós-graduando em Direito Civil e Processo Civil, da Faculdade UCAM e Membro do Núcleo de Pesquisa e Escrita da Faculdade Legale.

${ }^{2}$ Orientador. Doutorado em Ciências da Saúde. Mestrado em Letras. Graduação em Direito. Graduação em Letras.
} 
como método indutivo e nada obsta a integralidade de outros métodos por vias acidentais ou não. A pesquisa teve como fonte de referências: o auxílio da doutrina, da jurisprudência, das leis e da $\mathrm{CF} / 88$. Dessa maneira e por não ter um fim apriorístico este artigo encontra-se aberto para futuras explorações.

Palavras-chaves: Posse, criacionismo, propriedade.

\section{INTRODUÇÃO}

O assunto proposto neste artigo não teve o condão exauriente sobre o tema, que em síntese, teve como base fundante e aspiração, na inquietação do ser humano ao longo de sua existência no Planeta Terra. Neste esteio nascendo um desejo de conhecer, todavia conhecer não era o suficiente, era preciso ser igual ao criador, a fim de, conhecer a estrutura e a origem deste universo. Nessa esteira germinando em sua personalidade um manto de senhorio, um "ANIMUS DOMIN"', isto é, um ânimo de dono, fundada na posse. Ocorrência que se verificará mais adiante (no diálogo entre a serpente do campo e a mulher). Assim, foi observado e verificado por várias áreas do conhecimento, que essa inquietação, só ocorreu pela necessidade de ter uma relação mais próxima, mais íntima com universo ou com o seu criador. Um misto de (desejo e posse) que deveria ser dominado: devido aos seus efeitos positivos ou não positivos, a depender do caso concreto. Em relação a essas necessidades e seus aspectos, isto é, a maneira que elas se apresentam, serão abordados posteriormente e no momento apenas faço um convite, a fim de, chamar a atenção para algumas nuances: Parece-me que essa dualidade de desejo e posse é transcendental, mudando o rumo da história, ora afetando-a positivamente ora não afetando positivamente. Tal situação, pode ser a morada dos conflitos humanos, tendo como nascedouro a maneira de proceder e tendo como estopim ou gatilho, as percepções intrínsecas ou extrínsecas, a depender do grau e da força exercida. Causando assim, um desequilíbrio no desejo de se ter ou por outro lado, a paz de manter o que se têm: Quiçá, advindas do meio ou do ambiente que se vive. Dessa maneira e transmutando para os dias atuais a humanidade, seja por uma visão mística, religiosa ou científica, continua a pavimentar a estrada das teorias da cosmologia e da cosmogonia entre outras. Assim, sem desprezar as outras teorias e por entender que a marcha da 
humanidade não deve ser estagnada e tão pouco apriorística, passaremos a mencionar algumas dessas teorias:

a) A Teoria do Universo Holográfico: em apertada síntese nos informa que o universo é um gigantesco holograma (TALBOT, 1991).

b) [...]. A Teoria do Big Bang: por sua vez nos informa que o Universo surgiu de uma grande explosão; c) A Teoria da Relatividade Geral: se ocupou do espaço, tempo e movimento; d) A Teoria Heliocêntrica: para essa teoria o Sol é o centro do Universo e a Terra gira em seu redor (STEINER, 2006, p. 233 - 248).

Neste sentido, pela busca da estrutura e criação do universo e sem nenhum vínculo de catequese, optou-se pela teoria Criacionista por acreditar ser a mais adequada para a construção deste artigo. Dessa maneira, foi possível trazer uma abordagem sobre os aspectos históricos do direito de propriedade de bens imóveis, com substância na (escritura sagrada). E, assim ressaltar a relevância e a proteção conferida aquele que detém a posse desse bem. Nessa toada foi possível analisar os reflexos econômicos e a função social da propriedade, bem como, os limites constitucionais do direito de propriedade, seja no âmbito terreno ou no âmbito divino. Considerando os aspectos históricos que sem nenhuma dúvida pavimentaram e pavimentam a estrada da humanidade, nesta esteira, foi possível fazer uma imersão histórica, em relação às teorias elencadas neste artigo, mesmo em síntese apertada. Nessa perspectiva, a pesquisa caracteriza-se como método indutivo e nada obsta a integralidade de outros métodos por vias acidentais ou não. Diante do exposto a pesquisa deste artigo foi estruturada em 4 (quatro) capítulos, assim distribuídos: e) O Primeiro Capítulo traz uma abordagem do direito de propriedade a luz da teoria criacionista; f) O Segundo Capítulo verificou os reflexos econômicos e a função social da propriedade; g) O Terceiro Capítulo verificou os limites do direito de propriedade a luz da Constituição Federal de 1988; h) O Quarto capítulo verificou a ausência de propósito negocial, bem como, ausência de forma, consumando-se na extensão dos danos causados, advindos da (Lei, $n^{\circ}$. 14.223 de 2006.) Consubstanciado todos os capítulos concernentes a apresentação desse artigo, desejamos a todos uma boa leitura. 


\section{DIREITO DE PROPRIEDADE SEGUNDO AS LEIS DO CRIACIONISMO}

Neste capítulo foi verificado o direito do proprietário em face do possuidor, sabendose que ambos têm seu alicerce na posse. Fazendo assim uma analogia, segundo as luzes do criacionismo e nos termos que dispõe (as leis da Escritura Sagrada no livro de Gênesis, capítulo, 1ํ; 2ํㅜ ; 3) e nos termos da (Lei, nº10.406/2002). Continuando nessa perspectiva e sem ser elástico na interpretação, não é exagero dizer que: Foi o primeiro contrato realizado de forma verbal e pode ser classificado ou considerado por outro contorno, como: Contrato de Comodato Modal. Neste diapasão foi verificado nos termos, da Lei supra os seguintes artigos: Art. 579, Art. 582, Art. 584, Art. 585 e nas decisões festejadas pelos Tribunais. Neste ponto, consoante Art. 585, mencionado acima e respeitada as devidas proporções, cabe ressaltar que o Art. $2^{\circ}$ da Lei, $n^{\circ}$. 8.245 /91: denominada de modo comum de Lei do Inquilinato, também faz menção da responsabilidade solidária. Vejamos alguns precedentes verificados em relação ao Comodato Verbal e Modal.

Decisões do Tribunal (Sob o Registro: 2017.0000692055), ACORDÃO. Apelação $n^{\circ}$. 1007299-77.2015.8.26.0004. AÇÃO DE REINTEGRAÇÃO DE POSSE. Imóvel urbano. Ação fundada em extinção de comodato verbal, com prazo indeterminado (...) (BRASIL. TRIBUNAL DE JUSTIÇA DO ESTADO DE SÃO PAULO).

Ação fundada em extinção de comodato verbal, com prazo indeterminado Presença dos requisitos previstos no artigo 927, incisos I a IV, do CPC Posse direta exercida pela ré que não anula a indireta exercida pela autora - Notificação premonitória visando extinguir o comodato A permanência da ré no imóvel, após ser notificada para desocupá-lo, configura esbulho possessório Ré que não comprovou, tal como lhe competia, a teor do art. 333, II, do Código de Processo Civil, ocupar o imóvel na condição de locatária Pagamento de prestações do financiamento do imóvel que não descaracteriza o comodato Ação de reintegração de posse procedente Recurso improvido." (Ap. n. 000070317.2011.8.26.0269, Rel. Des. Plinio Novaes de Andrade Júnior, 24a Câmara de Direito Privado, j. em 1.10.2015.); (BRASIL. TRIBUNAL DE JUSTIÇA DO ESTADO DE SÃO PAULO).

Recurso Especial Ação de Manutenção de posse. Direito de retenção por acessão e benfeitorias. Contrato de Comodato Modal. Cláusulas 
Contratuais. Validade. (...) 3. A atribuição de encargo ao comodatário, consistente na construção de casa de alvenaria, a fim de evitar a "favelização" do local, não desnatura o contrato de comodato modal. 4. Recurso especial não provido". (STJ, REsp 1316895/SP Rel. Ministra Nancy Andrighi, j. em 11.06.2013.) (g/n) Diário de Justiça Eletrônica (28/06/2013) (BRASIL. SUPERIOR TRIBUNAL DE JUSTIÇA).

Reintegração de posse. Contexto probatório dos autos que autoriza o acolhimento da pretensão vestibular. Demonstrada a existência de comodato verbal e modal relativamente ao imóvel em questão. Sentença mantida. Recurso desprovido." (Ap. n. 0000104-66.2012.8.26.0003, Rel. Des. Luis Carlos de Barros, 20a Câmara de Direito Privado, j. em 14.3.2016.) (BRASIL. TRIBUNAL DE JUSTIÇA DO ESTADO DE SÃO PAULO.).

Diante do exposto, foi verificado no "Jardim do Éden" livro de Gênesis capítulo 2 versículo 17, Almeida, (1.996, p. 2), uma condição ou por assim dizer: uma cláusula proibitiva, uma obrigação de não fazer: Ordenou o senhor Deus, para não comerem da árvore do conhecimento do bem e do mal, pois no dia em que dela comer certamente morrerás. Essa inobservância contratual trouxe (uma cisão) e (dois efeitos), entre os quais podemos verificar a situação de duas mortes a saber:

\subsection{A PRIMEIRA SITUAÇÃO}

Faz referência com a morte no sentido espiritual ou em outras palavras a separação do homem em relação a Deus (Espírito). Assim, diante dessa abstração [existe um abismo entre o homem e esse espírito denominado (Deus) e nessa esteira fazendo referência a morte espiritual ou incorpórea. Seria a separação do homem espiritual em relação a Deus, causa futura espiritual: daí a ideia de religião no sentido de religar o homem em relação a Deus]. Ainda nesse raciocínio e por analogia, pode-se verificar em texto Constitucional, como norma afirmativa e garantidora do livre exercício dos cultos religiosos e a proteção a esses locais de culto e suas liturgias, nos termos do (Artigo $5^{\circ}$ e incisos, IV, VI, VIII da Constituição da República Federativa do Brasil de 1988). Nesses termos, torna clara a evidência e a existência de um Estado laico. Afastando de uma vez por todas o mito e a ideia comum da frase: O Estado é laico, más não é laicista. Neste diapasão foi verificado a diferença entre estado laico e laicista, 
Cristo ensinou: "dar a césar o que é de césar e a deus o que é de deus", isto é, o estado e a igreja têm atividades diferentes e devem atuar conjuntamente para o bem do povo. O estado é laico, quer dizer, não professa uma religião específica, mas deve incentivar o valor religioso, que faz parte da grandeza e da dignidade do homem. Laicidade, corretamente entendida, significa que o Estado deve proteger amplamente a liberdade religiosa tanto em sua dimensão pessoal como social, e não impor, por meio de leis e decretos, nenhuma verdade especificamente religiosa ou filosófica, mas elaborar as leis com base nas verdades morais naturais. $\mathrm{O}$ fundamento do direito à liberdade se encontra na própria dignidade da pessoa humana. [...] (FELIPE AQUINO, 2019).

Todavia há correntes favoráveis, concernente a retirada de determinado símbolo cristão dos departamentos ou repartições públicas, fundamentando que: Isto afeta outras profissões ou manifestações de Fé, tornando dessa maneira um Estado laico, más não laicista. Essa situação não deveria ser causa de certas celeumas e bastaria a leitura da Carta de intenções (Que assim dispõe: [...], promulgamos, sob a proteção de Deus, a seguinte CONSTITUIÇÃO DA REPÚBLICA FEDERATIVA DO BRASIL, 1988). Por outro contorno e com apreço aqueles que entendem de maneira oposta ou diferente, pode-se extrair a seguinte interpretação, do (Art. $5^{\circ}$ e inciso, IV, V, VIII da Constituição Federal de 1988.) Dessa maneira verificou-se que esse mesmo Deus representado simbolicamente por uma Cruz ou Crucifixo que apresenta a imagem do Cristo em certas repartições Públicas: não ofende ou afeta ou obriga ou constrange, qualquer cidadão brasileiro ou estrangeiro a seguir esse mesmo pensamento, seja por convicção filosófica ou política. Sendo apenas o próprio reflexo desse mesmo Estado laico, ou seja: A liberdade de consciência e de crença é, a livre manifestação do pensamento e por outro contorno a manifestação do espírito. Nesse sentimento de um Deus para se verbalizar individualmente ou ainda pelo uso do pronome, a fim de identificar certos grupos da mesma Fé e ordem. É evidente que os legisladores estavam se referindo ao Estado Brasileiro e sua organização Político-Administrativa. Afastando por antecedência qualquer conflito nessa seara da Religião. Sendo essa a moldura da harmonia e pacificação das controvérsias, garantindo na forma da lei o exercício de seus cultos e liturgias, bem como, a proteção desses locais, a fim de, atingirem sua função social material, quanto incorpórea. 


\subsection{A SEGUNDA SITUAÇÃO}

Faz referência com a morte física ou corpórea, seria a separação do homem em relação aos seus semelhantes, causa futura e material. Neste esteio pode-se verificar uma cisão corpórea e incorpórea entre o homem original (Adâmico) e seu criador. Por outro contorno e sem ser elástico na interpretação (no meu sentir é esta cisão que dá origem a ideia de entidade familiar, nos termos do (Artigo 226, parágrafo terceiro da Constituição Federal de 1988) bem como, a ideia de posse, nos termos do (Artigo 1.196, do Código Civil de 2002). Todavia, essa ideia de posse já era latente no Jardim do Éden.

Dessa maneira, o criador do Céu e da Terra e tudo que nela há, deixou um ensinamento: Quando se tratar de Lei, esta lei deve ser cumprida, obedecida, desde que, esteja em conformidade com a norma hierárquica superior ou por outros termos, que seja respeitado o pacto havido entre as partes (ALMEIDA, 1996; LIVRO DE GÊNESIS, CAPÍTULO 2, VERSÍCULO 17, p.2).

Assim, com a queda do homem do lugar denominado Jardim do Éden, este mesmo homem foi lançado para fora deste jardim. Isto caracteriza que o homem estava por sua conta e risco. Dessa maneira teve que trabalhar, cultivar, desbravar essa terra, semeando-a, protegendo-a, agindo como se dono o fosse e dela sobreviver. Porém o Criador não desamparou a Adão e sua mulher Eva, antes os vestiu e lançou para fora do Éden, para lavrar a terra de que fora tomado. Feito essas considerações é possível verificar que: Adão e sua mulher Eva, foram os primeiros habitantes a exercerem o direito de posse não plena. Nesta toada parece-me, que essa terra em que foi lançado Adão e sua Mulher, foi uma maneira de recompensá-los por seu trabalho e benefícios gerados no Jardim do Éden ou ainda nessa perspectiva (fora um gesto de manter a célula familiar, assentada no direito de posse, com finalidade habitacional campestre) e dessa maneira manter a sua sobrevivência e o seu desenvolvimento como ser humano, respeitando dessa maneira a projeção de sua personalidade advinda da dignidade da pessoa humana. Neste esteio, não podia deixar de ressaltar esse importante momento que o homem é lançado fora do Jardim do Éden. É, nesse exato momento que se verifica o direito de exercício pleno da propriedade (domínio), de reaver o bem aonde ele estiver, nos termos do (Art. 1.228 do Código Civil, 2002.). 
Pode-se verificar que a terminologia da palavra dispor a qual está contida no Art. 1.228 do mesmo código em comento: é apresentada de maneira genérica, podendo significar, uma doação com ou sem encargos, um comodato ou ainda uma outra maneira de liberalidade que possa haver entre os contratantes. Torna-se cristalino que há fortes evidências que o direito de propriedade em sentido lato sensu, historicamente teve suas bases de formação à luz da teoria criacionista, nascendo neste primeiro momento o conceito de posse, nos termos do (Artigo 1.196 do Código Civil de 2002, alhures mencionado). Um outro ponto importante sobre o direito de propriedade está esculpido na Bíblia Sagrada no livro de Êxodo. Nesta toada trazendo em seu bojo as Leis acerca da propriedade e entre as várias espécies de propriedades mencionadas neste livro, foi verificado no presente caso uma similitude da propriedade com o direito à vida. Enquadrando-se no conceito de legítima defesa combinado com a exclusão de ilicitude, nos termos do (Art. 23. Caput, inciso I, II, III c/c Artigo $1^{\circ}$ todos do Decreto-lei n. 2.848 de 1940.) c/c (Artigo. 188, incisos e parágrafo único da Lei n. 10.406 de 2002.).

Art. 23. Não há crime quando o sujeito pratica o fato: Inciso I- em estado de necessidade; Inciso I- em estado de necessidade, Inciso II, dispondo que: "não há crime quando o agente pratica o fato: em legítima defesa, Inciso III- em estrito cumprimento de dever legal ou no exercício regular de direito; Artigo 1ํ. Não há crime sem lei anterior que o defina. Não há pena sem prévia cominação legal. (Código Penal, 1940) c/c (Art.188. Não constituem atos ilícitos: Inciso I- os praticados em legítima defesa ou no exercício regular de um direito reconhecido, Inciso II- a deterioração ou destruição da coisa alheia, ou a lesão a pessoa, a fim de remover perigo iminente. Parágrafo único - No caso do inciso II, o ato será legítimo somente quando as circunstâncias 0 tornarem absolutamente necessário, não excedendo os limites do indispensável para remoção do perigo. (CÓDIGO CIVIL BRASILEIRO, 2002).

Diante desse fato curioso há fortes indícios de se posicionar o direito de propriedade no âmbito dos Direitos e Garantias Fundamentais, nos termos do Título II, Capítulo I dos Direitos e Deveres Individuais e Coletivos. Tais direitos e garantias estão elencados no Artigo Art. $5^{\circ}$. Caput e inciso II, XXII, XXIII, XXXV, XXXIX e outros,

Os quais dispõe sobre o tratamento equânime perante a lei, garantindo a inviolabilidade do direito à vida, à liberdade, à igualdade, à segurança e à propriedade. Estabelecendo que ninguém é obrigado a fazer ou 
deixar de fazer alguma coisa senão em virtude de lei. Garante também o direito de propriedade, trazendo como efeito imperativo da própria norma que a propriedade atenderá sua função social. (CONSTITUIÇÃO DA REPÚBLICA FEDERATIVA DO BRASIL DE 1988).

Nesta senda projetando-se também no âmbito do Direito Civil e Penal. Diante dessa observação foi possível verificar que a problemática está a recair nesse primeiro momento sobre o longa manus da vida, isto é, a propriedade. Assim, conferindo ao possuidor pleno ou não os poderes esculpidos nos termos da lei divina. Por outro contorno, também pode-se verificar uma ressalva, nos termos do capítulo 22, versículo terceiro do livro de Êxodo, "Se, porém, já havia sol quando tal se deu, quem o feriu será culpado do sangue." (ALMEIDA, 1996.). Nos termos do versículo acima verifica-se o enquadramento perfeito, nos artigos a seguir,

Art. 25. Entende-se em legítima defesa quem, usando moderadamente dos meios necessários, repele a injusta agressão, atual ou iminente, a direito seu ou de outrem c/c Art. 65 do Decreto-lei n. 3.689 de 1941. Faz coisa julgada no civil a sentença penal que reconhecer ter sido $o$ ato praticado em estado de necessidade, em legítima defesa, em estrito

cumprimento de dever legal ou no exercício regular de direito. (CÓDIGO PENAL BRASILEIRO. INSTITUÍDO PELO DECRETO-LEI N. 3.689 DE 1941.). Nesse sentido e ressalvadas as devidas proporções foi verificado,

Art. 1.210. O possuidor tem direito a ser mantido na posse em caso de turbação, restituído no de esbulho, e segurado de violência iminente, se tiver justo receio de ser molestado.

Parágrafo primeiro - O possuidor turbado, ou esbulhado, poderá manterse ou restituir-se por sua própria força, contanto que o faça logo; os atos de defesa, ou de desforço, não podem ir além do indispensável à manutenção, ou restituição da posse (CÓDIGO CIVIL BRASILEIRO DE 2002).

Verifica-se neste segundo momento que a problemática está a recair sobre a pessoa, em virtude do direito à vida. Retirando por assim dizer a excludente de ilicitude, a legítima defesa advinda da propriedade. Com o intuito de ressaltar que o direito de propriedade não é absoluto. Limitando assim a atuação da pessoa natural ou da pessoa jurídica de ordem pública ou privada, entendendo o termo propriedade como o conjunto de todos os bens da pessoa, corpóreos e incorpóreos. Sabendo-se que o 
direito está assentado sobre a tríade: Patrimônio, Vida e Liberdade, direitos esculpidos em normas Constitucionais e Infraconstitucionais. Diante dessa síntese e conforme Deus me permite ver o direito. Torna-se cristalino que (a terminologia propriedade é o princípio do gênero, dos quais são espécies o direito do proprietário ou o direito do possuidor a depender do caso em específico, a fim de, emanar seus efeitos). É, o que podemos inferir na grafia original,

[...] Se o proprietário, para garantir o que deve, sujeita a propriedade ao credor, obrigando-se á não aliena-la propriedade affectada-, dá se o direito real de hypotheca. Se desmembra o dominio, perpetua ou temporariamente, transferindo á outro a utilidade da cousa, dá-se o emphyteuse. Se transfere o direito de posse, uso ou gôzo, mais ou menos completamente,-propriedade dividida, gravada-, dão se os direitos reaes das servidões, superfície, usufructo, uso e habitação. Concebe-se, que o direito real de domínio recáia, e produza seus efeitos, sobre uma certa classe de bens moveis (81); entretanto, que possível é sempre cousas immóveis. segundo os ensinamentos de (TEIXEIRA DE FREITAS, 2003, p. 86-97).

Nessa esteira se faz relevante ressaltar que a Constituição Federal ora em vigor, garante o direito de propriedade, bem como, a função social da propriedade. É o que se extrai do Art. 5‥ Inciso XXII, XXIII da Constituição em comento. Dessa maneira enquadrando-se na moldura e nos termos da dignidade da pessoa humana, assegurando a todos existência digna, nos ditames do Art. 170, desta Constituição. Nestes termos a propriedade não é mais do que a posse e vise e versa. Desse modo, podemos inferir que a real baliza desses fenômenos tem seu fundamento na dignidade da pessoa humana ou seja, na projeção e no desenvolvimento de sua personalidade. É, o que se pode extrair, da Constituição em comento: Sendo assim, a partir desse princípio semeador e diretor, pode-se verificar a extração de outros, ou melhor: a germinação e o nascedouro de outros princípios equivalentes ou do mesmo quilate e hierarquia. Que em dado momento podem atuar: ora em defesa do direito do proprietário ora em defesa do direito da tutela da posse, a fim de trazer ao equilíbrio a função social da propriedade em determinado ente da federação, bem como, os princípios gerais da atividade econômica, nos termos do (Artigo 170 da CF/88.) Observa-se que a tutela da posse não é uma mera instrumentalidade da tutela jurisdicional do procedimento rígido do processo. Nesse esteio foi observado em que: 
a tutela da posse é um fato e um direito que apresentado para a apreciação do EstadoJuiz: o qual está jungido a dizer o direito, a fim de dirimir tal pretensão, seja em virtude da propriedade ou em virtude da posse. Tais situações podem ser verificadas, ressalvadas as devidas proporções, conforme discorre sobre a tutela da posse no atual sistema jurídico brasileiro,

O que se pode retirar como suma conclusiva do exposto é que posse e propriedade são institutos autônomos, tutelados sob enfoque de distintos princípios constitucionais. Harmônicos no plano normativo, os princípios do direito de propriedade e da função social das propriedades podem envolver-se em situações concretas de tensão, quando tracionam em direção oposta, a exigir solução de concordância prática que, fatalmente, importará a necessidade de limitação de um deles em benefício do outro, ou de ambos, em benefício comum do sistema. A Constituição, embora não assegure, explicitamente, um genérico "direito à posse", inegavelmente tutela a posse quando necessário para atingir finalidades específicas, entre as quais a da concretização do princípio da função social das propriedades. (ZAVASCKI, 2005, p. 21).

Também foi verificado dada as devidas proporções, nesta mesma toada, conforme os ensinamentos na lavra de Queiroz Lima (1917, p. 1-97) em que discorre, sobre: Patrimônio, domínio e posse. E, nessa tríade, trazendo a definição de propriedade ou Domínio, bem como, a escolha do Código Civil, pela terminologia propriedade. Demonstrando assim a importância do patrimônio, da propriedade e da posse plena ou não [que em dado momento a depender do caso concreto se fundirá em propriedade de maneira não original e revestida de legitimidade regressivamente positiva, adquirindo a moldura de seus direitos de proprietário, assumindo para si a responsabilidade das obrigações que possam recair sobre a propriedade, devido os seus acréscimos econômicos, sendo ressalvado nos casos específicos e nos termos da lei, devendo ser suscetíveis de apreciação econômica, formando assim todo o conjunto de seu patrimônio e seu arcabouço lógico no universo jurídico de direitos e obrigações, projetando tanto no direito positivo e no direito consuetudinário sua personalidade humana.] Durante a construção deste artigo foi possível verificar a ocorrência da inquietação do ser humano ao longo de sua existência. Essa inquietação ocorreu em primeiro lugar no Jardim do Éden: A partir do diálogo entre a Serpente do campo e a Mulher, nos termos da Bíblia da sagrada, 
Livro de Gênesis. capítulo 3. versículo 1- 24. [...] É assim que Deus disse: Não comereis de toda árvore do jardim? Respondeu a mulher à serpente: Do fruto das árvores do jardim podemos comer, mas do fruto da árvore que está no meio do jardim, disse Deus: Não comereis dele, nem nele tocareis, para que não morrais. Então a serpente disse à mulher: Certamente não morrereis. Por que Deus sabe que no dia em que comerdes desse fruto, os vossos olhos se abrirão, e sereis como Deus, conhecendo o bem e o mal. Vendo a mulher que aquela árvore era boa para se comer, e agradável aos olhos, e árvore desejável para dar entendimento, tomou do seu fruto, e comeu, e deu também a seu marido, que estava com ela, e ele comeu. [...] (ALMEIDA, 1.996. p. 2-3).

Devido a este comportamento e continuando nesse diálogo entre a serpente do campo e a mulher, torna clara a evidência da indução, despertando um desejo de posse, uma vontade de alma, uma transmutação com a finalidade de ser igual a Deus. É, nesse ponto que repousa a inquietude do ser humano, querendo se apossar de determinadas propriedades corpóreas e incorpóreas, fungíveis e infungíveis, afetando normas divinas ou normas terrestres. Nesse contexto foi verificado que: comer do fruto proibido não era o clímax da questão, mas sim a vontade de se apossar, de possuir o que não lhe pertence. Trata-se do momento da ação dramática em que a tenção atinge o seu mais elevado grau, articulando-se geralmente com um ponto de viragem decisivo (turning point), na sequência do qual ocorre o desenlace. Assim foi verificado na obra intitulada a Técnica do Drama:

[...] Considerou a existência de uma estrutura piramidal, com uma ação ascendente, um clímax e uma ação descendente. A ação ascendente começa com a exposição e intensifica-se através da complicação até atingir o clímax. A ação descendente passa por aquilo que Aristóteles designou como peripeteia (uma súbita mudança que altera o rumo dos acontecimentos) em direção ao desenlace, cuja configuração varia em função do gênero em que a peça se integra. (FREYTAG'S, 1900, p. 101, 112-114).

Isto posto, o que ocorreu no diálogo havido entre a serpente do campo e a mulher, afetou os princípios de uma norma hierarquicamente superior. Nesses termos ao dar ouvidos a serpente do campo, tanto a mulher quanto o homem, afetaram uma norma superior, desobedecendo os limites a eles conferidos. Afetando assim as normas da lei divina, alterando-se assim o rumo dos acontecimentos. Neste contexto pode-se verificar e denominar essas normas, como: normas de observância da hierárquica 
superior em face de lei hierárquica inferior. É sabido que nessa época a lei não era como hoje a concebemos e nesses termos foi verificado de maneira análoga a Teoria Pura do Direito segundo Kelsen (1998) a qual dispõe sobre a hierarquia das normas. Nesta linha de raciocínio, a inquietação do ser humano, em nada obsta a exteriorização do desejo, de ter uma relação mais próxima, mais íntima com o universo, desde que, respeitada a hierarquia das normas vigentes, a depender do caso concreto. Na mesma toada não se descarta a participação de outras áreas do conhecimento, a saber: O conhecimento Antropológico; O conhecimento Matemático e o conhecimento Sociológico e Filosófico. Nesse passo, não se descarta a participação de outras teorias, bem como, aquelas teorias expressas na introdução deste artigo. Até porque, essas teorias em conjunto com outras áreas do saber, fundamentam o suporte que orienta a inquietação do ser humano em desvendar a origem do universo e sua relação com este mesmo universo. Haja vista as teorias expressas em momento anterior, apenas faremos uma chamada a fim de trazer a memória, vejamos: A Teoria do Universo Holográfico, essa Teoria em apertada síntese nos informa que o universo é um gigantesco holograma. A Teoria do Big Bang, essa teoria nos informa que o Universo surgiu de uma grande explosão. A Teoria da Relatividade Geral, essa teoria se ocupou do espaço, tempo e movimento. A Teoria Heliocêntrica, para essa teoria o Sol é o centro do Universo e a Terra gira em seu redor. Diante do exposto, pode-se verificar os aspectos cosmológicos os quais estudam a estrutura do universo e por outro lado podemos verificar os aspectos da cosmogonia os quais estudam a origem do universo. Neste esteio fica clara a evidência em que: de maneira suplementar, essas teorias completam e enriquecem, no sentido de melhor compreender quem é este ser humano (homem) e quais os motivos de suas inquietações em relação ao universo em que vive. Dessa maneira foi observado por várias áreas do conhecimento que esta inquietação só ocorreu pela necessidade de ter uma relação mais próxima, mais íntima com o universo. Nesse passo, nascendo um desejo de participar, todavia participar não era o suficiente era preciso conhecer a estrutura e a origem deste universo e neste sentido foi verificado conforme os seguintes periódicos e suas respectivas revistas. No periódico da Revista da Universidade de São Paulo, assim descrito por Steiner, 


\section{RESUMO.}

OS VÁRIOS MODELOS cosmológicos ao longo da história são brevemente descritos. A evolução das idéias pode ser entendida como uma sucessão de modelos, como o da Terra plana, o dos modelos geocêntricos, o do heliocêntrico e o do galactocêntrico. Nos últimos cem anos foi desenvolvida uma teoria, a do Big Bang, que descreve as observações mais sofisticadas de que dispomos hoje e que mostra que o universo teve uma origem que pode ser pesquisada cientificamente. Em décadas recentes, esse modelo foi aperfeiçoado para um novo conceito, o do Big Bang inflacionário. Na virada do milênio, novas descobertas mostraram que toda a matéria conhecida é apenas a ponta do iceberg em um universo dominado pela energia escura e pela matéria escura cujas naturezas permanecem misteriosas. (REVISTAS USP, 2006, p. 231-248).

No periódico da Revista da Universidade Federal de Minas Gerais. Os autores Francisco; Luiz e Gabriel, descrevem os seguintes assuntos,

O modelo de universo mais aceito pela comunidade científica, conhecido como modelo cosmológico padrão, prevê que o universo teve início há cerca de pouco mais de 14 bilhões de anos. Esse instante inicial é denominado de Big Bang. Após o Big Bang, o universo expandiu e se resfriou. No primeiro milionésimo de segundo, ou logo após este intervalo, existiam quarks, glúons, elétrons e neutrinos. Prótons e nêutrons surgiram após 0,0001 de segundo. A formação de átomos leves ocorreu três minutos depois, ao passo que os átomos neutros formaramse após 400 mil anos.

$\mathrm{Na}$ próxima seção, descreveremos a "batalha cósmica", tendo a gravitação e a liberação de energia como seus protagonistas e, como resultado, a formação dos elementos químicos mais leves. Em seguida, apresentaremos a formação das estrelas e o aparecimento da vida [...] (REVISTA DA UFMG, 2012, p. 182-205).

Dito isto, fica consubstanciado a existência da Cosmologia e da Cosmogonia, bem como, seus efeitos na ansiedade do ser humano em conhecer ou aproximar-se da estrutura e da origem do universo,

cosmología (do gr. kosmos: mundo, e logos, ciência, teoria) Conjunto das teorias científicas que tratam das leis ou das propriedades da matéria em geral ou do universo. Toda cosmo-logia supõe a possibilidade de um conhecimento do mundo como sistema e de sua expressão num discurso. Por isso, a imagem do sistema do mundo é determinante para toda filosofia que se pretende sistemática. 
postulado de uma totalização do mundo, pelo saber, revela-se indispensável a uma eventual totalização do próprio saber. (JAPIASSÚ; MARCONDES, 2006).

cosmogonia (gr. kosmogonia: criação do mundo) Teoria sobre a origem do *universo, geralmente fundada em lendas ou em *mitos e ligada a uma metafísica. Em sua origem, designa toda explicação da formação do universo e dos objetos celestes. Atualmente, designa as explicações de caráter mítico. Ex.: as cosmogonias pré-socráticas de Tales de Mileto, Anaximandro, Empédocles etc. (JAPIASSÚ; MARCONDES, 2006).

Isto posto e transmutando para os dias atuais a humanidade, seja por uma visão mística ou religiosa ou científica, continua a pavimentar a estrada das teorias da cosmologia e da cosmogonia entre outras. Neste sentido pela busca da estrutura e criação do universo optou-se pela teoria Criacionista, com fundamento nas Escrituras Sagradas, livro de Gênesis, por acreditar ser a mais adequada para a construção deste artigo. Dessa maneira foi verificado nos termos assim dispostos na Bíblia Sagrada,

Livro de Gênesis, capítulo 1ำ - 3o. No princípio criou Deus os céus e a terra. A terra era sem forma e vazia; havia trevas sobre a face do abismo, e o Espírito de Deus pairava sobre a face das águas, [...] Ora, plantou o Senhor Deus um jardim no Éden [...], O Senhor Deus tomou o homem e o pôs no jardim do Éden para o lavrar e guardar. [...], O Senhor Deus, pois, o lançou fora do jardim do Éden, para lavrar a terra de que fora tomado. [...], pôs querubins ao oriente do jardim do Éden e uma espada flamejante que se revolvia por todos os lados, para guardar o caminho da árvore da vida. (ALMEIDA, 1996, p. 2-3).

Assim, nos termos da Escritura Sagrada foi verificado no livro de Gênesis no capítulo primeiro até o capítulo terceiro, que: o princípio e a autoria da criação dos céus e da terra e tudo que nela há. Nasce neste ato de criação divina o primeiro direito de propriedade intelectual ou direito autoral e nessa toada por fortes indícios é possível que o legislador abeberou desta fonte de criação divina quando esculpiu o Artigo $1^{\circ}, 7^{\circ}$ na Lei, $n^{\circ}$. 9.610/1988,

Art. 10: Esta Lei regula os direitos autorais, entendendo-se sob esta denominação os direitos de autor e os que Ihes são conexos; Art. $7^{\circ}$ São obras intelectuais protegidas as criações do espírito, expressas por qualquer meio ou fixadas em qualquer suporte, tangível ou intangível, conhecido ou que se invente no futuro, tais como [...]. (BRASIL, LEI, N. 9.610 DE 1988.). 
É sabido que a lei supramencionada teve como escopo proteger e garantir os direitos do autor a fim de, expressar por meios artísticos, literários, científicos a sua vontade do espírito, ou seja, a manifestação de sua capacidade intelectiva. Em momento posterior, concernente a criação divina e saltando um pouco mais na história, verificase que: foi conferido ao homem lavrar e guardar este Jardim denominado de "Jardim do Éden". Nesta linha de pensamento foi concedido ao homem a posse deste jardim e dele poder se alimentar, dos frutos, exceto da árvore do conhecimento do bem e do mal, más no dia que dela comer, certamente morrerás. Diante dessa Lei divina podese observar que há fortes indícios que o legislador continua a beber na mesma fonte de criação divina vejamos,

Art. 1.196. Considera-se possuidor todo aquele que tem de fato o exercício, pleno ou não, de alguns dos poderes inerentes à propriedade.

Art. 1.197. A posse direta, de pessoa que tem a coisa em seu poder, temporariamente, em virtude de direito pessoal, ou real, não anula a indireta, de quem aquela foi havida, podendo o possuidor direto defender a sua posse contra $o$ indireto.

Art. 1.214. O possuidor de boa-fé tem direito, enquanto ela durar, aos frutos percebidos. (BRASIL, CÓDIGO CIVIL BRASILEIRO DE 2002).

Assim, nos termos da Bíblia Sagrada no livro de Gênesis. Foi verificado uma condição de posse não plena e uma obrigação de não fazer:

Livro de Gênesis. Capítulo 2. Versículo 16. Ordenou o Senhor Deus ao homem, dizendo: De toda a árvore do jardim comerás livremente, Versículo 17. mas da árvore do conhecimento do bem e do mal, dela não comerás, pois no dia em que dela comeres, certamente morrerás. (ALMEIDA, 1996. p. 2)

Torna clara a evidência que o homem não estava no Jardim do Éden na condição de jardineiro, caseiro, administrador ou ainda na condição de detentor do Jardim do Éden. Todavia sua condição era de posse direta, por uma razão lógica: existia ali um proprietário que exercia o pleno domínio da propriedade. Por essa ótica o homem do jardim do Éden era possuidor deste jardim e havia uma ordem verbal e direta a qual limitava o direito do possuidor. Assim, foi verificado que entre Deus e o homem havia um contrato verbal e com a quebra desse contrato: Deus passa a exercer o pleno 
direito de proprietário erigido do domínio da propriedade fundada na posse do denominado, Jardim do Éden. Assim formulados em seus poderes de: usar, fruir, dispor e reaver o bem aonde ele estiver ou em virtude da posse, tecnicamente denominada de (nua-propriedade). Dessa maneira reavendo este bem, com base no direito e no exercício pleno de domínio da propriedade. Nesta esteira se verificou uma cláusula contratual que incide na resolução do contrato havido entre as partes, isto é, entre Deus e o Homem, conforme dito em outro momento. Situação tal, em que emerge do Artigo. 5‥ Inciso - XXXV da Constituição da República Federativa do Brasil de 1988: "A Lei não excluirá da apreciação do Poder Judiciário lesão ou ameaça a direito."

Conforme foi verificado na Escritura Sagrada, Versículo 20 e 21, Almeida (1996, p.3). Devido a resolução contratual foi verificado a título de curiosidade: o momento em que o homem passou a ser chamado de Adão e por sua vez a Mulher passou a ser chamada de Eva: "Chamou o Homem a sua mulher Eva, porque era a mãe de todos os viventes; Fez o Senhor Deus vestimenta de peles para Adão e sua mulher, e os vestiu." Nestes termos e superada a curiosidade, fica consubstanciado o direito do proprietário e do possuidor indireto de exercer o direito, a guarda ou a proteção possessória nos termos da Lei divina e terrena. Assim, diante de todo o exposto a luz da teoria criacionista, mesmo que em síntese, foi possível observar e verificar a importância do Direito de Propriedade e o Direito da Posse. Ficando caracterizado mais uma vez que a posse é um fato e um direito. Esses direitos, têm por escopo resguardar o direito do proprietário, bem como, o direito do possuidor, todos fundados na posse. Sabendo-se que a existência da posse depende da existência da propriedade. E no caso vertente, no sentido material e imaterial, a fim de alcançar sua função social e econômica, que deve ser erigida tanto da propriedade, quanto da posse. Nesse sentido nos informa a doutrina,

Bem se vê, destarte, que o princípio da função social diz respeito mais ao fenômeno possessório que ao direito de propriedade. Referida função "é mais evidente na posse e muito menos na propriedade", observa a doutrina atenta, e daí falar-se em função social da posse. [...] (REALE, 1999, p.8; FACHIN, 1955, p. 19 apud ZAVASCKI, 2005, p. 2). 
Neste raciocínio se faz importante ressaltar que: As ações possessórias são meios instrumentais das formalidades rígidas da tutela jurídica do processo, com o escopo de obter do Estado-Juiz, a (tutela jurisdicional), sendo essa tutela uma sentença de mérito que poderá ser uma sentença procedente ou improcedente. Por outro viés nada obsta a solução das demandas pela tutela do direito, ou seja, pela mediação extrajudicial ou judicial, nos termos das referidas leis e Resolução do Conselho Nacional de Justiça,

Dispõe sobre a mediação entre particulares como meio de solução de controvérsias e sobre a autocomposição de conflitos no âmbito da administração pública; altera a Lei $n^{\circ} 9.469$, de 10 de julho de 1997, e o Decreto $n^{\circ} 70.235$, de 6 de março de 1972 ; e revoga o $\S 2^{\circ}$ do art. $6^{\circ}$ da Lei $n^{\circ} 9.469$, de 10 de julho de 1997. (LEI, № 13.140 de 26 de junho de 2015.).

Art. $3^{\circ}$ Não se excluirá da apreciação jurisdicional ameaça ou lesão a direito.

$\S 2^{\circ}$ O Estado promoverá, sempre que possível, a solução consensual dos conflitos.

$\S 3^{\circ}$ A conciliação, a mediação e outros métodos de solução consensual de conflitos deverão ser estimulados por juízes, advogados, defensores públicos e membros do Ministério Público, inclusive no curso do processo judicial. (Lei, $\mathrm{n}^{\circ}$. 13.105 de 16 de março de 2015.).

Dispõe sobre a Política Nacional de tratamento adequado dos conflitos de interesses no âmbito do Poder Judiciário e dá outras providências. Política Judiciária Nacional; Conflitos de interesse; meios consensuais; Núcleos Permanentes de Métodos Consensuais de Solução de Conflitos; Treinamento e capacitação [...] (RESOLUÇÃO DO CONSELHO NACIONAL DE JUSTIÇA (CNJ) n. 125 de 29 de novembro de 2010.).

É claro que naquela época, isto é, no Jardim do Éden, era uma função social de cunho Alimentar e Familiar rural e nesse passo, podemos até dizer que era uma situação de atividade agrícola familiar e destituída neste primeiro momento de capacidade econômica propriamente dita. Assim, verificaremos no próximo capítulo os reflexos econômicos e a função social da propriedade conforme hoje a concebemos. 


\section{REFLEXO ECONÔMICOS E FUNÇÃO SOCIAL DA PROPRIEDADE}

Em relação a este capítulo verificou-se em síntese apertada: em que, os reflexos econômicos e a função social da propriedade propriamente ditas, isto é, de domínio pleno e por outro contorno fazendo uma distinção entre reflexos econômicos e a função social da propriedade. Sabendo-se que os reflexos econômicos de certa maneira, atuam na seara social a Stricto Sensu, todavia não se confundem com a função social da propriedade, pois esta contém uma amplitude, abarcando outras situações não contidas nos reflexos econômicos. Porém, sem perder sua característica econômica direta e indireta ou denominada no meu sentir, de: Reflexos Econômicos Interna Partes e Externa Partes. Isto posto, passaremos a analisar os reflexos econômicos advindos da propriedade, entendendo-se nesse primeiro momento a propriedade no sentido (prédio) residencial, comercial, ou Prédio urbano edificado ou Prédio rústico de área contínua ou ainda a pequena propriedade rural. Ainda que esta propriedade seja concretizada por aquisição realizada ou firmada na compra e venda ou por intermédio do direito de sucessões ou ainda adquirida pela ação pessoal de usucapir e agindo como se dono o fosse ou segundo outros entendimentos: pelo Instituto do Usucapião urbano ou rural ou pelo instituto da desapropriação para fins de reforma agrária. No contexto acima caberia mencionar a locação residencial que de certo modo traz um acréscimo econômico para o locador e de certo modo a depender do caso concreto poderia trazer também um acréscimo econômico para o locatário: sabendo-se que este, poderia ser contratado para exercer seu ofício laboral por causa da proximidade com o local de trabalho, bem como, a infraestrutura do local poderia Ihe proporcionar um certo acréscimo econômico. Neste mesmo sentido de acréscimo econômico se enquadraria a locação não residencial e o Comodato, respeitando as devidas proporções de cada um. Sendo assim, seguindo os princípios gerais da atividade econômica, dispostos no Ordenamento Pátrio ora em vigor, nos termos do Art.170. Dessa maneira indo de encontro com a garantia do direito de propriedade e a função social a qual deve atender, nos termos constitucionais. Por outro contorno, trazem um acréscimo econômico advindo de um comando, de um dispositivo de norma Constitucional, regulamentado por Lei infraconstitucional. Seja pelo direito de sucessões ou por usucapião ou advindos da 
doação ou da desapropriação ou por via testamentária. Neste contexto ao invés de despender com alugueres, terá a possibilidade de investir e de manter os quesitos básicos de sua família, ou seja, os seus direitos fundamentais inerentes àqueles que constituem e fazem parte de determinada sociedade. Neste ponto foi verificado que: além de ter um caráter de abrigar o ente familiar, proporciona para este, uma melhoria em sua qualidade de vida e no seu desenvolvimento como pessoa humana. Nesse contexto se verifica que os reflexos econômicos advindos do direito de propriedade podem ser classificados ou denominado como: Reflexos Econômicos Interna Partes e Externa Partes. Deste modo os Reflexos Econômicos Interna Partes serão percebidos em primeiro passo, no seio familiar, como uma sensação do efeito abstrato advindo desse reflexo econômico. É claro que não estamos posicionando-o, como uma expectativa de direito ou ainda como um direito subjetivo ou de escolha ou ainda de direito futuro e incerto. Nesse caso, o reflexo posicionado acima será revertido de alguma maneira à entidade familiar, tendo em seus efeitos de aplicabilidade, como norma autônoma hipotética, a qual se concretizará como Reflexos Econômicos Externa Partes, independentemente de uma decisão a ser aplicada por determinada entidade familiar. Assim, esse comando de norma abstrata, vai de encontro a norma hipotética fundamental de Kelsen (1881-1973):

(...) Finalmente deve notar-se que uma norma pode ser não só o sentido de um ato de vontade mas também - como conteúdo de sentido - o conteúdo de um ato de pensamento. Uma norma pode não só ser querida, como também pode ser simplesmente pensada sem ser querida. Neste caso, ela não é uma norma posta, uma norma positiva. Quer isto dizer que uma norma não tem de ser efetivamente posta - pode estar simplesmente pressuposta no pensamento. (KELSEN, 1881-1973, p. 7,267$)$.

Para KELSEN a validade traduz o modo de existência peculiar das normas. Em outras palavras, a norma só é válida se emanada de um ato legítimo de autoridade, não tendo sido por ela revogada. Tal ato representa a condição para sua validade, mas não o seu fundamento de existência. O fundamento de uma norma, segundo o criador do purismo jurídico, está contido em outra norma, a qual ele denomina norma hipotética fundamental. (SOARES, 2002).

(...) A teoria da norma jurídica, segundo Hans KELSEN, fundamenta-se na distinção entre o sein (ser) e o sollen (dever), ou, seja, na existência 
do mundo físico, sujeito às leis da causalidade, e do mundo social, sujeito às leis do espírito, as quais, sendo leis de fins, podem ser traduzidas em normas

A norma fundamental de KELSEN possui um caráter hipotético: (...) (REALE, 1998, p. 167, apud SOARES, 2002).

Diante dessa breve exposição foi possível verificar por uma análise ampliada que: O direito de propriedade respeitada as devidas proporções é uma parte do desdobro ou desmembramento da extensão da territorialidade nacional. Nesse contexto não seria suficiente apenas a posse ou condição registral concernente a propriedade de bens imóveis, também não seria suficiente apenas a condição de Soberania Nacional. Assim, foi verificado mais uma vez que a posse é composta pelos elementos que a individualizam, independe da abstração jurídica aplicada em cada caso específico. A título de exemplificação foi verificado na Revista Veredas da História, consoante artigo confeccionado por Felipe Rabelo Couto (200, p. 55-85): a questão da posse entre Brasil e Bolívia e a solução dada nesta questão da Territorialidade do ACRE. Nesse passo o objeto diretor é a proteção do solo, da terra, do chão (onde estão assentados a propriedade ou os limites territoriais a serem exercidos em nome do direito de posse ou de domínio: daí decorrem os direitos individuais e coletivos seja das pessoas naturais ou jurídicas de direito privado ou público ou ainda aqueles de âmbito internacional. Assim tal proteção só ocorrerá mediante a posse, seja ela plena ou não, lembrando que posse é um estado de sentimento e a propriedade sua confirmação, más o domínio a todas preenchem). Dessa maneira, torna-se imperioso ressaltar que: Entre outras formas constitucionais, a exemplo da desapropriação e leis esparsas. A propriedade pode ser adquirida por intermédio da compra e venda; pelo direito de sucessões; por usucapião; por doação ou ainda pelo registro do título. Assim encartados no Código Civil Brasileiro,

No Título V- Dos Contratos em Geral, podemos citar os contratos firmados na compra e venda, nos termos do Art. 421 e seguintes; no Título VI Das várias Espécies de Contrato, pode-se mencionar o Art. 481, 482 e seguintes; no Livro V Do Direito das Sucessões pode-se mencionar o Art. 1.784 e seguintes; no Capítulo II Da Aquisição da Propriedade Imóvel, podemos citar aqueles adquiridos por usucapião nos termos do Art. 1.239, 1.240, 1.240-A, 1.241, 1.242; no Capítulo IV Da Doação, pode-se mencionar o Art. 538 e seguintes; na Seção II Da 
Aquisição pelo Registro do Título, temos o Art. 1.245 e seguintes. (CÓDIGO CIVIL BRASILEIRO DE 2002).

Neste sentido foi observado que a simples presença de uma propriedade rústica (rural) ou urbana, impulsiona a Organização do Estado a garantir e respeitar os direitos e obrigações concernentes a estes assuntos, os quais estão esculpidas no Artigo 5, Inciso, XXX; Artigo 60: todos da Constituição Federal de 1.988. Seja em relação à União, bem como, seus entes federados, isto é, o Estado ou Município em virtude do direito real de propriedade, pleno ou não. Sobre estes direitos, dada as devidas proporções, pode-se verificar seus reflexos diretos concernentes na dignidade da pessoa humana e nessa toada de maneira indireta refletindo também nos direitos sociais. Esses princípios e direitos constitucionais são ERGA OMNES e devem ser observados, respeitados e garantidos na forma da lei. Até porque: Nascem com a posse plena ou não, da propriedade, isto é, nascem com a fixação do homem ao solo. Desse modo caracterizando-se além da posse e indo de encontro a sua nacionalidade e sua naturalidade geograficamente falando. Alongando-se pelos laços de sangue concernente a filiação. Retomando em linhas gerais a ideia original deste artigo, verifica-se mais uma vez a importância da (Posse) no direito de propriedade, bem como, sua exaustiva proteção. Sabendo-se que essa proteção, em se tratando de direito real da propriedade de bens imóveis, será exercida a quem detém a posse, seja ela plena ou não. Nessa linha de raciocínio verificou-se a mesma ocorrência de proteção no sentido de sua territorialidade, nacionalidade e naturalidade ou filiação. As quais estão abarcadas no termo JUS SOLI (direito de solo) e JUS SANGÜINIS (direito de sangue). Embora sejam autônomos entre si: completam-se de modo SUI GENERIS, a fim de garantir o direito de posse, assim conceituado,

Retenção ou fruição de uma coisa ou de um direito., Estado de quem possui uma coisa, de quem detém como sua ou tem o gozo dela., Ação ou direito de possuir a título de propriedade., Fortuna, haveres., Capacidade, aptidão., Meios, forças; alcance, tomar posse: meter de posse, dar posse, diz-se de ato pelo qual alguém é investido ou investe outrem num direito, num cargo ou dignidade. (BRASIL, DICIONÁRIO AURÉLIO).

Sabendo-se que a posse é considerada pelo exercício de fato. O qual, considera possuidor todo aquele que tem de fato o exercício pleno ou não, de alguns dos 
poderes inerentes à propriedade. Desse modo se verificou: que a questão do solo funciona como um plano diretor a conduzir outros ramos do direito em seus efeitos. Seja, na seara Constitucional, Civil, Penal, Tributária etc. Dessa maneira o Estado (União) atrai para si a sua soberania, distribuindo as devidas competências da estrutura política, isto é, da Organização do Estado, contida em suas normas constitucionais ou (normas constitucionais principiológicas). Funcionando como diretrizes a serem observadas e respeitadas, pelas Leis infraconstitucionais. Isto pode ser verificado no Ordenamento Pátrio ora em vigor: que traz o tratamento adequado da Organização Político-Administrativa, funcionando assim como um verdadeiro "Cheks and Balances" (freios e contrapesos). É, essa balança de equilíbrio que regula e auto regula-se, no intuito de limitar os poderes de atuação: seja do Estado (União) ou seja em relação aos entes federados, ou em relação aos seus súditos ou ainda um em face do outro. Sendo assim, segundo Montesquieu (2000, p.19): respeitando dessa maneira as normas constitucionais principiológicas e assim, mantendo a separação dos poderes para se obter uma administração descentralizada. Facilitando ou possibilitando a aplicabilidade do exercício da norma programática Constitucional, para conferir e dar (eficácia plena ou restringível) ou ainda (limitada) à norma Programática Constitucional. Sejam elas imediatas ou mediatas, as quais, estão expressas no corpo e no termo preliminar do Ordenamento Pátrio em vigor. E, dessa maneira, poder direcioná-las às atividades de seus súditos, garantindo a participação desses em todo o contexto que os englobam.

\section{LIMITES CONSTITUCIONAIS NO DIREITO DE PROPRIEDADE}

Neste capítulo foi verificado os limites Constitucionais do direito de propriedade, conforme expresso em texto constitucional, decretos e leis federais entre outras leis esparsas. Assim mencionaremos neste primeiro momento: as diretrizes, bem como, os limites esculpidos na Constituição Federal de 1988: (Art. $5^{\circ}$ Caput e inciso XXIV, XXV) c/c (Art. 136 Caput e parágrafo primeiro, inciso segundo); (Art.137 Caput e inciso I); (Art.139 Caput e incisos I-VII e $\S$ único); (Art. 243). Nessa linha de raciocínio também foi verificado nos termos do Decreto $n^{\circ}$. 54.535, de 30 de outubro de 2001, 
Decreto n. 54.535 de 30 de out. 2013. Ementa. Confere nova redação aos artigos $3^{\circ}, 4^{\circ}, 5^{\circ}, 6^{\circ}, 7^{\circ}, 10,11,13,14$ e 18 do Decreto $n^{\circ}$. 53.799, de 26 de março de 2013, que estabelece o procedimento a ser observado para a desapropriação de bens úteis ou necessários aos interesses da Administração Municipal. (DIÁRIO OFICIAL DA CIDADE DE 31/10/2013, p. 1).

Nessa esteira foi verificado nos termos do Decreto-lei Federal, №. 3.365 de 1941, dispondo sobre desapropriações por utilidade pública e neste sentido foi verificado na Lei, ํo. 4.132/1962,

(Art. 1ํ A desapropriação por interesse social será decretada para promover a justa distribuição da propriedade ou condicionar o seu uso ao bem estar social, na forma do Art. 147 da Constituição Federal); (Art. $2^{\circ}$ Considera-se de interesse social: inciso I - 0 aproveitamento de todo bem improdutivo ou explorado sem correspondência com as necessidades de habitação, trabalho e consumo dos centros de população a que deve ou possa suprir por seu destino econômico [...] (BRASIL, CÂMARA DOS DEPUTADOS).

Sendo assim: os artigos constitucionais citados em outro momento, estão em consonância com os Decretos e leis já mencionados. Seja no que diz respeito aos limites ou mitigações do uso da propriedade. Todavia exista pensamentos adversos em relação a preponderância da União para exercer a desapropriação em face dos seus entes federados, entre esses pensamentos podemos trazer a lumen: (MARÇAL, 2015; CARVALHO, 2008). Isto posto, torna-se clara a evidência em relação aos entes elencados a exercer sua autonomia em face da desapropriação na forma da lei. Nessa toada podemos verificar que a Constituição do Império já abarcava os limites constitucionais os quais afetam o uso do direito da propriedade ou em outras palavras: o direito do proprietário em relação a propriedade. Neste diapasão foi verificado na grafia original, nos termos do PROMPTUARIO DAS LEI CIVIS (SIC), STF PATRIMÔNIO N. ${ }^{\circ} 12539.9$,

Direito de propriedade a única excepção á plenitude delle, conforme o Art, $179 \S 22$ da Const. do Imp., terá lugar quando o bem publico exigir o uso, e emprego da propriedade do cidadão, por necessidade ou utilidade - Lei de 9 de Setembro de 1826, Lei, $\mathrm{n}^{\circ}$. 353 de 12 de Julho de 1845. (FREITAS, 1876, p. 212-213, 224) 
Diante da abordagem ao longo deste artigo, torna-se cristalino os limites daquele que detém a posse, bem como, os limites da autonomia do Estado em face da mitigação dos direitos e garantias dessa mesma posse. Desse modo também foi possível verificar a importância conferida a função social e econômica da propriedade.

\section{A EXTENSÃO DOS DANOS CAUSADOS ADVINDOS DA LEI CIDADE LIMPA}

A referida lei vem dispor sobre os objetivos, as diretrizes, a fim de manter um meio ambiente ecologicamente equilibrado. Trazendo também nesse bojo as estratégias e definições em relação aos elementos que compõem a paisagem urbana do Município de São Paulo. Neste sentido, indo de encontro aos princípios e preceitos republicanos e democráticos de direito, os quais, norteiam todo o Ordenamento Pátrio. Sendo assim, não se questiona a concorrência comum da municipalidade esculpida na Constituição Federal de 1.988, em que dispõe,

Art. 23. É competência comum da União, dos Estados, do Distrito Federal e dos Municípios: Inciso Vl. proteger o meio ambiente e combater a poluição em qualquer de suas formas. Art. 30. Compete aos Municípios: I - legislar sobre assuntos de interesse local; II - suplementar a legislação federal e a estadual no que couber; [...] (BRSIL, CONSTITUIÇÃO FEDERAL DE 1988).

Sabendo-se que a Constituição em comento, dispõe sobre a competência comum da União e seus entes federados, a fim de, protegerem o meio ambiente e combater a poluição em qualquer de suas formas. Neste sentido, foi verificado na mesma Constituição em comento, bem como, se verificou na Lei Orgânica do Município de São Paulo e na Lei Municipal de São Paulo:

Preâmbulo Nós, representantes do povo do Município de São Paulo, reunidos em Assembléia Constituinte, respeitando os preceitos da Constituição da República Federativa do Brasil, promulgamos, sob a proteção de Deus, a presente Lei Orgânica, que constitui a Lei Fundamental do Município de São Paulo, com o objetivo de organizar o exercício do poder e fortalecer as instituições democráticas e os direitos da pessoa humana. Art. 13. Cabe à Câmara, com sanção do Prefeito, não exigida esta para o especificado no artigo 14, dispor sobre as matérias de competência do Município, especialmente: (Alterado pela 
Emenda 05/91) Inciso I - legislar sobre assuntos de interesse local; Inciso II - suplementar a legislação federal e estadual, no que couber; [...] (LEI ORGÁNICA DO MUNICÍPIO DE SÃO PAULO.).

Dispõe sobre a ordenação dos elementos que compõem a paisagem urbana do Município de São Paulo. "Art. 32. Para efeitos desta lei, são solidariamente responsáveis pelo anúncio o proprietário e o possuidor do imóvel onde o anúncio estiver instalado. [...]." (MUNICÍPIO DE SÃO PAULO, Lei no. 14.223/2006.).

Desta maneira foi possível constatar: que há uma enorme diferença entre competência comum e competência de interesse local ou suplementar, em seu cabimento, seja em relação a legislação federal ou estadual. Nesta toada foi observado, conforme considera o Art. 32, da Lei, n. 14.223/2006: a qual, impõe a responsabilidade solidariamente concernente a atividade empresarial ou empresária, posicionando o locador como se sócio o fosse das respectivas atividades. Nesta esteira, elencamos resumidamente duas decisões entre outras do Tribunal de Justiça do Estado de São Paulo (TJSP), em desfavor do Município de São Paulo,

Decisões do Tribunal (Sob o Registro: 2018.0000081077, ACORDÃO, Apelação ํo. 1040212-28.2016.8.26.0053, multa administrativa destituída de natureza proter rem); também foi verificado ser incabível a solidariedade disposta no Art. 32, da "Lei Cidade Limpa" sob o Registro: 2018.0000608504, ACORDÃO, Apelação Cível/Reexame Necessário/Multas e demais Sansões oㅡ 0100869-31.2008.8.26.0053). (BRASIL, Tribunal de Justiça do Estado de São Paulo.).

Neste ponto a referida lei em comento afeta a Lei, Federal $n^{\circ}$. 8.245, de 14 de outubro de 1991. Dispõe sobre as locações dos imóveis urbanos e os procedimentos a elas pertinentes, assim dispondo em seu Art. $1^{\circ}$ e Parágrafo único: "A locação de imóvel urbano regula-se pelo disposto nesta Lei. Parágrafo único - Continuam regulados pelo Código Civil e pelas leis especiais." Nesta esteira não pode a municipalidade legislar sobre direito civil e muito menos impor responsabilidade solidariamente entre - Locador e Locatário, afetando assim a boa-fé, os bons costumes e a liberdade contratual, nos termos da Lei, №. 10.406, de 10 de janeiro de 2002. Nos termos em que dispõe o artigo 421. A liberdade de contratar será exercida em razão e nos limites da função social do contrato; artigo 422. Os contratantes são obrigados a guardar, assim na conclusão do contrato, como em sua execução, os princípios de probidade 
e boa-fé. Desta maneira afeta a livre iniciativa esculpida, nos termos do Art.170, da Constituição de 1988. Por derradeiro afeta o direito de escolha do consumidor e inviabilizando a circulação de mercadorias, afetando todo o arcabouço que envolve a cadeia consumerista. Sendo assim, a "Lei Cidade Limpa", ultrapassa sua competência legislativa quando intervém diretamente na relação Contratual havida entre o Locador e o Locatário ou comodante e o comodatário de imóvel residencial urbano ou não residencial urbano, bem como, nas empresas e profissionais, segundo dispõe o Artigo. 32 e parágrafos da Lei, nº.14.223/2006.

Art.32 Para efeitos desta lei, são solidariamente responsáveis pelo anúncio o proprietário e o possuidor do imóvel onde o anúncio estiver instalado. Parágrafo 1‥ A empresa instaladora é também solidariamente responsável pelos aspectos técnicos e de segurança de instalação do anúncio, bem como de sua remoção. Parágrafo $2^{\circ}$. Quanto à segurança e aos aspectos técnicos referentes à parte estrutural e elétrica, também são solidariamente responsáveis os respectivos profissionais. Parágrafo 3․ Quanto à segurança e aos aspectos técnicos referentes à manutenção, também é solidariamente responsável a empresa de manutenção. Parágrafo 4ํ․ Os responsáveis pelo anúncio responderão administrativa, civil e criminalmente pela veracidade das informações prestadas. (MUNICÍPIO DE SÃO PAULO, Artigo. 32 e parágrafos da Lei, no.14.223/2006).

Sendo assim, foi Observado e verificado na Parte Especial do Livro I do Direito das Obrigações, do Código Civil Brasileiro de 2002 e nos termos da Lei, n‥ 8.078 de 11 de setembro de 1990. Assim, pode-se verificar que estes diplomas legais entre outras leis, trazem a tratativa, bem como, a competência concernente a cada caso em específico, mencionado no Art. 32 e parágrafos da "Lei Cidade Limpa". Tornando-se translúcida sua afetação e ausência de competência comum nestes casos. Nessa toada, mais uma vez a municipalidade inova situações e conflita-se com o ordenamento das normas Constitucionais e Infraconstitucionais, bem como, afeta Leis Federais e Leis estaduais: As quais não the confere tal abrangência. Nesse passo perde-se o seu objeto por distanciar da ordem normativa a ser por ela suplementada. Dispondo além do seu cabimento legislativo suplementar. Posicionar tal responsabilidade solidariamente à proprietário ou possuidor, bem como, as empresas prestadoras de serviços e seus respectivos profissionais, impingindo-Ihes obrigações adversas: é inovar o ordenamento constitucional. Neste diapasão se torna forçoso e 
Antirrepublicano tal responsabilidade solidariamente imposta pelo legislador, ferindo assim, os princípios democráticos de um Estado de Direito. Desse modo o legislador interfere no Pacta Sunt Servanda, pacto este concernente apenas aos celebrantes ou contratantes ou ainda tecnicamente falando aos Transmitentes, bem como, interfere nas suas vocações sucessórias ou ainda um terceiro interessado que venha a ser afetado, seja nos seus direitos ou em suas obrigações. Nesta esteira não basta apenas a vontade do legislador e se faz necessário respeitar a máxima de quem pode mais, também pode menos. Assim, a Lei, n. 14.223/2006, não tem o condão de lei especial, trata-se no caso vertente: de uma lei de competência comum e de interesse local, conforme dito em outro momento. Insta ressaltar os ensinamentos em que dispõe,

[...] a Constituição Federal de 1824, confere a municipalidade atribuições administrativas, nos termos do Ato Adicional n. $1^{\circ}$ de outubro do mesmo ano, adotada pela Lei 12 de agosto de 1824. Com a advindo da Lei de n. $1^{\circ}$ de outubro de 1828 , todas as Cidades e Vilas do Império passaram a ser compostas pelas respectivas Câmaras Municipais. Possibilitando assim, cuidar dos seus interesses comunitários. Alguns anos depois o rigorismo da constituição ora em comento foi amenizado com o advento e a adoção do Ato Adicional de 1834[...] (NOGUEIRA, 2012, p. 12, 2122),

Nesse ponto, de acordo os dizeres,

Calmon, em sua tese, A Federação e o Brasil:

Calmon, denominou esse sensível abrandamento da Carta Política de 1824, como: semefederalismo. Todavia no entendimento dos respectivos autores: José de Aguiar dias; Alcino Pinto Falcão. Esse abrandamento ocorreu devido a aplicação do princípio da devolução, qualificação dada pela doutrina moderna. Por esse princípio o Governo central devolve o exercício de certas competências, mantendo assim a subordinação dos governos locais. (FALCÃO; DIAS apud NOGUEIRA, 2012, p. 22).

Nessa toada e saltando no tempo e na história: no Artigo 18, do Ordenamento Pátrio de 1988, dispõe sobre a organização político-administrativa da República Federativa do Brasil. Assim compreendida pela União, os Estados, o Distrito Federal e os Municípios, nos termos desta Constituição. Assim, foi verificado no Ordenamento ora 
em vigor a autonomia político-administrativa, isto nos remete para $\circ$ Art. $2^{\circ}$, da Constituição Federal de 1.988. Dispondo sobre os poderes da União, no que diz respeito a sua autonomia, a sua harmonização dos poderes, elencando assim: o Legislativo, o Executivo e o Judiciário. Destarte, que esses poderes independentes e harmônicos entre si, continuam a pontilhar a condição dos seus atos políticos e administrativos. Pois este, isto é, o legislador: deve respeitar a separação dos Poderes e seus limites, a fim de evitar certa afetação nas relações havidas no seio social e por estar jungido por norma hierarquicamente superior e por Lei Federal e por Lei Estadual. Por outro contorno, considerando que esses locatários, venham a afetar leis ambientais de qualquer natureza, devemos lembrar que a locação é uma espécie de cessão de uso dos direitos reais advindos da propriedade. Seja por prazo determinado ou indeterminado, alcançando assim o possuidor pleno ou não. Sabendo-se que não existe posse sem propriedade e nem propriedade sem posse, devido a sua condição sui generis. Nesse contexto se faz importante ressaltar, nos termos do Art. 23, da Lei, $n^{\circ} .8 .245 / 1991$.

Art. 23. O locador é obrigado a: (...); Inciso II. servir-se do imóvel para o uso convencionado ou presumido, compatível com a natureza deste e com o fim a que se destina, devendo tratá-lo com o mesmo cuidado como se fosse seu; (...).

Continuando nesse contexto, foi verificado que o legislador, nos termos do Art. 582, da Lei, $n^{\circ}$. 10.406, de 2002,

Art. 582. confere ao Comodatário a mesma obrigação. O comodatário é obrigado a conservar, como se sua própria fora, a coisa emprestada, não podendo usá-la senão de acordo com o contrato ou a natureza dela, (...).

Conferiu a mesma obrigatoriedade para o comodatário em relação finalidade, cuidar e zelar como se fosse seu. Diante dos referidos artigos, foi verificado em que: $O$ ânimo de dono, nesses casos em específico, recai sobre o locatário e o comodatário por força da própria lei. Essa vontade do legislador, atrai para o locatário, bem como, para o comodatário a responsabilidade pelo uso da coisa locada ou emprestada. Desse modo não se atendo aos direitos reais, pois estes recaem sobre a propriedade a exemplo do Imposto Territorial Urbano (IPTU) ou Imposto Territorial Rural (ITR). 
Nessa toada, foi verificado que: [no meu sentir o legislador reveste o locatário e o comodatário com o ANIMUS DOMINI NORMATIVO CONSTITUCIONAL, isto é, com o sentimento de dono, com alma de dono, com procedimentos de dono, por meio de um comando imperativo da normatividade cogente]. Nessa esteira o legislador reforça a tese do direito de posse, fundada na propriedade, na posse plena ou não, ou ainda no direito de superfície e de laje. Sendo esses os objetos de locação, de comodato ou referentes a locação ou empréstimos de bens imóveis. Torna-se cristalino a anemia e a confusão advinda do Art. 32, da "Lei Cidade Limpa", anteriormente mencionado, bem como, sua flagrante ausência operacional, seja por eivar de vícios a Norma Constitucional, em que dispõe, "Art. 22. Compete privativamente à União legislar sobre: Inciso I - direito civil, comercial, penal, processual, eleitoral, agrário, marítimo, aeronáutico, espacial e do trabalho; (...)."

Afetando dessa maneira a competência privativa da União e / ou ainda por afetar outros ramos do direito. Isto posto, deve-se levar em consideração nos termos do parágrafo único, do Art.23, da Constituição Federal de 1988,

Art. 23. É competência comum da União, dos Estados, do Distrito Federal e dos Municípios:

Parágrafo único. Leis complementares fixarão normas para a cooperação entre a União e os Estados, o Distrito Federal e os Municípios, tendo em vista o equilíbrio do desenvolvimento e do bemestar em âmbito nacional.

No tocante a Lei complementar $n^{\circ}$. 140/2011. Essa por sua vez, traz as ações administrativas do Município de São Paulo, assim dispostas no Art. 9, da mesma lei complementar em comento,

Art. 9․ São ações administrativas dos Municípios: Inciso I - executar e fazer cumprir, em âmbito municipal, as Políticas Nacional e Estadual de Meio Ambiente e demais políticas nacionais e estaduais relacionadas à proteção do meio ambiente; Inciso II - exercer a gestão dos recursos ambientais no âmbito de suas atribuições; (...).

A Lei Complementar oㅜ 140 de 08 de dezembro de 2011. Fixa normas, nos termos dos incisos III, VI e VII do caput e do parágrafo único do art. 23 da Constituição Federal de 1.988: para a cooperação entre a União, 
os Estados, o Distrito Federal e os Municípios nas ações administrativas decorrentes do exercício da competência comum relativas à proteção das paisagens naturais notáveis, à proteção do meio ambiente, ao combate à poluição em qualquer de suas formas e a preservação das florestas, da fauna e da flora.

Sendo assim, altera o art. 1ำ da Lei no.6.938, de 31 de agosto de 1981. Nesse ponto a Lei Municipal não está autorizada para dispor livremente sobre regras gerais em relação ao meio ambiente e tão pouco lhe é conferida a legislar sobre o direito de posse plena ou não, bem como, o direito de superfície ou ainda impingir responsabilidade solidária as empresas e profissionais em suas prestações de serviços. Sabendo que tal ato, caberia ao Estado: por delegação da União ou na ausência de normas gerais sobre o respectivo tema, nos termos, do Art. 24, I, V, VI, VIII e parágrafos, todos da (CRFB/1988),

Art. 24. Compete à União, aos Estados e ao Distrito Federal legislar concorrentemente sobre: Inciso I - direito tributário, financeiro, penitenciário, econômico e Urbanístico; Inciso V- produção e consumo; Inciso VI - florestas, caça, pesca, fauna, conservação da natureza, defesa do solo e dos recursos naturais, proteção do meio ambiente e controle da poluição; Inciso VIII - responsabilidade por dano ao meio ambiente, ao consumidor, a bens e direitos de valor artístico, estético, histórico, turístico e paisagístico. Parágrafo primeiro - No âmbito da legislação concorrente, a competência da União limitar-se-á a estabelecer normas gerais. Parágrafo segundo - A competência da União para legislar sobre normas gerais não exclui a competência suplementar dos Estados. Parágrafo terceiro - Inexistindo lei federal sobre normas gerais, os Estados exercerão a competência legislativa plena, para atender suas peculiaridades. Parágrafo quarto - A superveniência de lei federal sobre normas gerais suspende a eficácia da lei estadual, no que lhe for contrário.

Nessa toada entrando em consonância com as Leis: Lei, $n^{\circ}$. 7.735/89; Lei $n^{\circ}$. 7.797/89; Lei, $n^{\circ} .7 .802 / 89$ regulamentada pelo Decreto 4.074/2002; Lei, n. 9. 605/98 e Art. 225, da (CRFB/1988). Sabendo-se que a Constituição Federal de 1988 é muito mais do que um guia ou plano diretor do Estado Brasileiro, significa por assim dizer: que o Ordenamento Pátrio é sem dúvida o maior Patrimônio do nosso País. Respeitosamente é o grande balcão de prestação de serviços e ofertas de produtos, seja em suas relações internas ou externas. Desse modo podemos evidenciar que o Executivo, o Legislativo e o Judiciário, embora independentes e harmônicos entre si: 
Devem obediência a Estrutura existente na $\mathrm{CF} / 88$. Neste sentido a separação dos poderes nos informa a amplitude e os limites que os definem. Assim Buarque de Holanda (1996), em sua ótica e de maneira cristalina nos informa: "definir é explicar o significado de alguma coisa, indicar o seu verdadeiro sentido." Isto posto, passamos então a tecer algumas considerações a respeito do tema Publicidade; Propaganda e Marca. Precipuamente se faz importante ressaltar qual a diferença de Publicidade e Propaganda e assim, posteriormente definir o que é Anúncio Indicativo. Sabendo-se que o legislador não traz tal definição, nos termos do art. $6^{\circ}$, da Lei, $n^{\circ}$. 14.223/2006. Destarte, dificulta a defesa do Munícipe, seja na seara Administrativa ou no âmbito Judicial, isto se verifica consoante as Apelações elencadas em momento anterior. Isto só ocorre, devido a forma genérica e imprecisa do conteúdo esculpida na referida lei. Levando em consideração que a lei em comento vai além da tratativa do meio ambiente, do Direito Urbanístico e do uso do solo: comportando nesse raciocínio o Direito Tributário, Direito Administrativo, Direito Penal, o Direito esculpido no Código de Defesa do Consumidor, entre outros. Comporta também uma vasta quantidade de normas constitucionais e infraconstitucionais, afetando dessa maneira o que se denomina de Direito Público. Sendo assim: o locador (proprietário) não tem nenhuma relação com Autos de Infração e multa, advindas sobre o estabelecimento em razão do exercício da atividade empresarial ou por sociedade empresária ou ainda por empresa despersonalizada, isto é, sem personalidade jurídica, realizada em imóvel locado. Dessa maneira foi verificado quem exerce atividade empresarial ou empresária nos termos do Art. 966 e seguintes; Art. 1.142 e seguintes; Art.1.150 e seguintes, todos do Código Civil Brasileiro, de 2002. Nesse raciocínio lógico a lei em comento "Cidade Limpa" imobiliza o locador, punindo-o, com o respectivo Auto de infração e multa. Parece-me que esta foi a maneira que o Município encontrou, por ser o meio mais fácil para aplicar o Auto de Infração e Multa, transmitindo responsabilidade fiscalizatória para o munícipe. Sendo assim, fazendo-o como se sócio fosse de tais empresas, com fundamento no Artigo. 32, da Lei Municipal $n^{\circ}$. 14.223 de 2006, bem como, no poder de Polícia conferido a administração Pública. Tudo isto, sobre o "Manto do meio ambiente." Nessa toada transformando Auto de Infração e Multa, como se fosse uma punição para o locador, que deveria fiscalizar e orientar os procedimentos da atividade empresarial, concernente ao meio ambiente. 
Assim, por não efetuar tal fiscalização, a municipalidade em nome do Art. 32, da Lei Cidade Limpa, transforma e considera o proprietário como Sujeito Passivo da obrigação Principal, sem avaliar o caso concreto. Desse modo, posicionar o locador como responsável solidariamente pelas atividades empresariais que supostamente venham a afetar todo o arcabouço de normas e leis, concernentes ao meio ambiente é no mínimo forçoso. Nessa esteira, sobre o termo Publicidade, nos socorremos segundo os ensinamentos da doutrina,

Publicidade é o ato comercial de índole coletiva, patrocinado por ente Público ou Privado, com ou sem personalidade, no âmago de uma atividade econômica, com a finalidade de promover, direto ou indiretamente, o consumo de produtos e serviços. (NUNES JUNIOR, 2001, p. 21-23).

De acordo com o referido autor: ele continua tecendo a classificação da Publicidade,

Segundo Vital Serrano Nunes Júnior e Yolanda Alves Pinto Serrano: O aspecto subjetivo, pode-se dizer que faz referência a certos amparos patrocinados por instituições Públicas ou Privadas; O conteudista tem uma vinculação econômica; O finalístico tem por objeto direto ou indireto promover a venda de produtos ou serviços por intermédio de efetiva divulgação; $O$ aspecto material por sua vez está ligado a acontecimento da comunicação social, lembrando-se que não é toda comunicação social que se integrará no conceito de publicidade. (SERRANO e SERRANO, 2003, p. 214).

Dessa maneira os autores classificaram a publicidade em quatro aspectos fundamentais, ou seja: o aspecto Subjetivo, o Conteudístico o Finalístico e o Material. Para estes autores, Propaganda é toda forma de comunicação, direcionada ou dirigida ao público determinado ou não, que, empreendida por pessoa física ou jurídica, pública ou privada, tenha por escopo a propagação de ideias concernentes à filosofia, à política, à economia, à ciência, à religião, à arte ou à sociedade. Verifica-se assim, que a terminologia Anúncio é extraída dos Termos Publicidade e Propaganda. Sabendo-se que na publicidade a finalidade é: promover tendo por objeto o lucro e na propaganda a finalidade é a propagação de ideias, concernentes a filosofia, a política, a economia, a ciência, a religião, a arte ou a sociedade. Isto Posto, verifica-se mais uma vez a imprecisão e a forma genérica que se apresenta a Lei Cidade Limpa. Esta Lei considera todo Anúncio como se fosse Publicidade, logo tudo é publicidade ou 
seja: Anúncio Indicativo; Anúncio Publicitário; Anúncio Especial; nos termos da Lei 14.223/2006, Art. 6. Caput, inciso I, alíneas "a", "b", "c". Diante do exposto, torna clara a evidência que o Município de São Paulo, equivoca-se: quando generaliza e qualifica o termo Anúncio, equiparando-o e conferindo ao termo Anúncio o status de publicidade ou Logotipo ou Logomarca. Sabendo-se que estes, estão umbilicalmente ligados na Publicidade ou na Propaganda, devido a condição SUI GENERIS do termo Anúncio: que ora funciona no sentido de publicidade ora no sentido de propaganda. Primeiramente a confusão dos termos acima ocorre devido as dúvidas, quanto a sua aplicação e dessa maneira é utilizado com propósitos diferentes, seja em relação aos leigos ou acadêmicos do meio Publicitário e do Designer. Assim não se deve confundir Marca, com Logotipo, sabendo-se que no âmbito da Comunicação o Logotipo é a representação gráfica do nome da empresa. Já no âmbito Publicitário e Acadêmico da Comunicação, Logotipo é a representação do nome da empresa de maneira estilizada, de modo a caracterizá-la. Assim para caracterizá-la se faz necessário o uso de letras e cores específicas, tornando-os únicos e revestidos de exclusividade e suscetíveis para fim de registro no Instituto Nacional de Propriedade Industrial (INPI). Torna-se cristalino que o Logotipo é uma representação da Marca e nesse sentido poderá ser considerado um Anúncio de Publicidade e/ou de propaganda, a depender de cada caso concreto: desde que utilizados fora do local onde se exerce a atividade, nos termos da alínea "b", inciso I, do Caput do Art. $6^{\circ}$ da Lei, $n^{\circ} 14.223 / 2006$. Em relação ao Anúncio Especial, esse está disposto na alínea "c" da referida Lei em comento, por sua vez o Anúncio indicativo: aquele que visa apenas identificar, no próprio local da atividade, os estabelecimentos e/ou profissionais que dele fazem uso; [...]. Nesse sentido o Locador ou o Locatário que: não se enquadrar na moldura Publicidade, conforme considera a Lei Cidade Limpa, visto que: não se configurando como Anúncio Indicativo, Anúncio Publicitário, Anúncio Especial ou logotipo ou logomarca, bem como, não se verificando nenhuma estilização de modo a caracterizar por sua tipografia ou símbolo que a representa. Não pode o Locador ou Locatário ser afetado por tal imposição da Lei Municipal n. 14.223 de 2006, conforme mencionado linhas acima. Sabendo-se que: A grande maioria dos casos que chegam aos Tribunais, trata-se apenas de Marcas, Logotipos ou do nome empresarial (nome fantasia), mas isto veremos mais adiante. Em relação a logomarca, essa por sua vez, 
foi incluída no dicionário português como sinônimo de Logotipo: devido ao uso comum pelos leigos. Porém não é bem aceita pelos publicitários e designers que a considerarem de certa maneira como um neologismo impreciso. Com referência a Marca, essa por sua vez, traz uma diferenciação de produtos ou serviços, ou seja: A Marca é utilizada apenas para distinguir um produto ou serviço de outro idêntico, semelhante ou afim, de origem diversa, nos termos do Art. 123, I, da lei, $\mathrm{n}^{\circ}$. 9.279/1996. Sabendo-se que também existe a Marca de Certificação e a Marca Coletiva, nos respectivos Inciso, II, III, da mesma lei em comento. Assim podemos adicionar os ensinamentos de Guimarães (2005) concernentes a definição de marca, "por definição, marca é considerado todo signo distintivo aposto, opcionalmente, aos produtos e serviços." Nessa esteira, tornando-se apenas suscetíveis de registro como Marca e após o registro, torna-se, ERGA OMNES, isto é, contra todos. Assim os Sinais Distintivos visualmente perceptíveis, quando registrados, funcionam como norma garantidora e exclusiva daquele que a registrou. É o que se pode extrair, nos termos do Art. 122 da Lei, n. 9.279 /1996. Nessa esteira, frisa-se: A proteção ao nome empresarial decorre automaticamente do arquivamento dos atos constitutivos de firma individual e de sociedades, ou de suas alterações, nos termos do Art. 33, da Lei, $\mathrm{n}^{\circ}$. 8.934/1994: A qual dispõe sobre o Registro Público de Empresas Mercantis e Atividades Afins e dá outras providências. Dito isto, foi verificado, nos termos do Art. 13, da "Lei Cidade Limpa" que: ao Município cabe regularizar as dimensões, readequações a depender do caso concreto. Sendo assim, deve precipuamente informar o Munícipe para efetuar a padronização de sua Marca ou de seu nome registral (empresarial) ou logotipo: Em atendimento a Lei, №. 12.527/2011, nos termos dos Artigos: (Art. $1^{\circ}$, Parágrafo único e inciso, I, II); (Art. 9‥ Caput. Inciso, I, alíneas "a"; "b"; "c", e inciso II); (Art. 45); (Art. 32 e inciso, I, II, III), [...] Nessa toada, fazer cumprir o que dispõe no Art. 41, Caput. Inciso I, II da Lei, №. 14.223/06, possibilitando o exercício regular de direito, disposto no Art. 13. Caput. Parágrafo $1^{\circ}$ e incisos, I - IV; e parágrafos seguintes. Assim, torna-se cristalino que tanto a Marca ou logotipo, quanto o nome Registral não se configuram na moldura Publicidade. Conforme dito anteriormente, nem toda comunicação social se integrará no conceito de publicidade. Nestes termos, seja a Marca ou o nome Registral (empresarial) ou mesmo o Logotipo ou como querem alguns Logomarca. Essas, por sua vez, fixadas na fachada de seus 
empreendimentos, aonde desenvolvem suas atividades empresariais ou empresárias, não as tornam passíveis de conceituação publicitária, seja em relação ao Anúncio Indicativo ou Especial. Sendo assim, podemos verificar,

O nome da pessoa física ou jurídica a que pertence o fundo de empresa é nome de pessoa, e não nome de coisa, e não entra na classe dos sinais distintivos, se não no que, designando a pessoa física ou jurídica, confere ao estabelecimento ou produto ou mercadoria valor a mais ou desprestígio. Esse plus, aliás eventual, é que pode ser tratado como bem incorpóreo. (PONTES DE MIRANDA, p. 4).

No mesmo sentido de Pontes de Miranda, ressalvados alguns aspectos. Foi verificado por Vasconcellos (1957, p.5) de acordo com Tomazette (2013, p. 126-133), trazem o entendimento em que o nome serve para "apartar a coisa dentre outras", distinguir um empresário de outros. É sabido que existem diferentes entendimentos em razão da natureza jurídica do nome empresarial, sendo assim verificou-se,

a) Pontes de Miranda; Alexandre Freitas de Assumpção Alves; Gladston Mamede; Daniel Adensohn de Souza; Adriano de Cupis: entendem tal natureza como direito de personalidade; b) Para João da Gama Cerqueira; Giuseppe Valeri; Sérgio Campinho e Francesco Ferrara Júnior: entendem tal natureza como direito de propriedade; c) Para J. X. Carvalho de Mendonça e Marlon Tomazette; Ricardo Negrão: estes entendem como direito pessoal. (TOMAZETTE, 2017, p. 183 - 185).

Dito isto, com todo respeito aos seletos e nobres doutrinadores, o nome empresarial tem sua natureza jurídica, não apenas por uma questão registral ou por uma questão de direito de propriedade, de direito de personalidade ou de direito pessoal, embora esses traços estejam presentes corpóreos ou incorpóreos. Sendo assim, sua natureza jurídica advém do Direito Público insculpido no (Art. 1ํ, inciso III, da CF/88); (inciso, XIV, XXXII, do Art. 5ª̣, da CF/88 c/c (Lei, nª . 8.078/1990, Art. 1ª̂).Verifica-se dessa maneira uma natureza jurídica de ordem pública, lastreada na dignidade da pessoa humana, fortalecendo o alcance da lei e garantindo o equilíbrio da atividade econômica, da livre concorrência, do princípio da veracidade e do princípio da informação ao fim que se destina, ou seja: Proporcionando o equilíbrio do objeto da seara consumerista, seja em virtude da proteção do nome empresarial ou da proteção ao direito do consumidor. Preservando o valor econômico do nome empresarial, 
embora de ordem pública não se descaracteriza pelo princípio da informação que the dá publicidade e com essa não se confunde, alongando-se sua função social em virtude do nome empresarial. Neste mesmo sentido de conceituar Anúncio como se fosse publicidade já estava sendo aplicado pelo Município de São Paulo, nos termos da Lei, $\mathrm{n}^{\circ}$. 13.474, de 30 de dezembro de 2002. (A qual dispõe sobre a Taxa de Fiscalização de Anúncios e dá outras providências), bem como: Lei, nº 12.115 - de 28 de junho de 1996 (Regulamentada pelo Decreto $n^{\circ}$. 36.646/1996) (Revogada pela Lei, $n^{\circ}$. 13.525/2003).

A qual dispõe sobre a ordenação de anúncios na paisagem no município, fixa normas para a veiculação desses anúncios, e dá outras providências. Conforme foi verificado na Revista de Informação Legislativa e consubstancia nas Breves notas introdutórias, vejamos

[...] Assim, pretende-se que os poderes públicos, de ordinário, passem a ter o dever de observar os direitos assegurados em sede constitucional [...]. A colisão entre princípios constitucionais, mormente no caso de direitos fundamentais, requer que uns tenham moderada sua aplicação em face de outros. Sublinhe-se, no entanto, que eventual limitação ou o seu cabimento deve ter apoio no texto constitucional. Não há restrição a direito fundamental sem base constitucional (ALEXY, 1993, p. 277; MIRANDA, 2000, p. 307). Significa dizer que eventual abrandamento, restrição ou privação da propriedade somente é admissível se houver inequívoco fundamento na Constituição[..]. (LEAL, 2012, p. 56).

Nesta visão da Propriedade como direito fundamental. Foi verificado a assertiva do autor e o equívoco do Município do Estado de São Paulo, na aplicação da "Lei Cidade Limpa" a qual afeta frontalmente os vários âmbitos do direito fundamental em relação a propriedade. Neste ponto, foi verificado a inexistência de aporte e de suporte jurídico em texto constitucional que possa dar guarida a hermenêutica aplicada pelo Município de São Paulo (SUBPREFEITURAS). Caracterizando dessa maneira a confirmação da ausência do Princípio da Eficiência, Princípio da Informação, Princípio da Moralidade, Princípio da Dignidade da Pessoa humana, entre outros. Dessa maneira o ato administrativo torna-se nulo de pleno direito ou anulável, todavia permaneça a legalidade do ato administrativo a depender do caso em específico. Por outro contorno torna-se carecedora de exigibilidade por ausência de identificação do sujeito passivo da obrigação pretendida pela Administração Pública. Nesse passo, observar-se-á apenas a significação lógica do termo princípio e, a base essencial, que forma todo conhecimento filosófico ou científico envolvendo a existência de princípios, ou ainda as exposições lógicas, que admitem como condição ou base de validade entre 
outras significações de certos campos do saber, conforme os respectivos doutrinadores,

Princípios são enunciações normativas de valor genérico que condicionam e orientam a compreensão do ordenamento jurídico, a aplicação e integração ou mesmo para a elaboração de novas normas. [...] São verdades fundantes de um sistema de conhecimento, como tais admitidas, por serem evidentes ou por terem sido comprovadas, mas também por motivos de ordem prática de caráter operacional, isto é, como pressupostos exigidos pelas necessidades das pesquisas e da práxis. (REALE, 2003, p. 37.).

Violar um princípio é muito mais grave que transgredir uma norma qualquer. A desatenção ao princípio implica ofensa não apenas a um específico mandamento obrigatório, mas a todos os sistemas de comando. É a mais grave forma de ilegalidade ou inconstitucionalidade, conforme o escalão do princípio atingido, porque representa insurgência contra todo o sistema, subversão dos seus valores fundamentais, contumélia irremissível a seu arcabouço lógico e corrosão de sua estrutura mestra. Isto porque, com ofendê-lo, abatem-se as regras que o sustêm e alui-se toda a estrutura nelas esforçada. (BANDEIRA DE MELLO, 2000, p. 748.).

Segundo a Revista de Informação Legislativa, [...] Princípios de uma ciência são as preposições básicas, fundamentais, típicas, que condicionam todas as estruturações subsequentes. Neste sentido, princípios, são os alicerces, os fundamentos da ciência[...] (SENADO FEDERAL).

Dessa maneira foi verificado: a municipalidade deve se abster de restringir direitos fundamentais, dos quais podemos elencar, nos termos do inciso, IX, XXIX, do Art. $5^{\circ}$, da Constituição Federal ora em vigor, entre outros. Na dicção do Artigo. 38. Parágrafo segundo $\left(\S 2^{\circ}\right)$, inciso I, II; Parágrafo terceiro $\left(\S 3^{\circ}\right)$, Parágrafo quarto $\left(\S 4^{\circ}\right)$, do Decreto $\mathrm{n}^{\circ}$. 50.895, de $1^{\circ}$ outubro de 2009. Para desconsiderar ato ou negócio jurídico simulado que visem a reduzir o valor do tributo, a evitar ou postergar seu pagamento ou a ocultar os verdadeiros aspectos do fato gerador ou a real natureza dos elementos constitutivos da obrigação tributária, dever-se-á levar em conta, entre outras, a ocorrência de: falta de propósito negocial ou abuso de forma, [...]. Verifica-se no Artigo. 38, parágrafo segundo, do Decreto em comento, duas hipóteses a se considerar. A Primeira é a falta de propósito negocial e, a segunda abuso de forma. Sendo assim, a primeira configura-se na falta de propósito negocial que: nos termos do Artigo. 38, 
parágrafo terceiro, traz a opção da forma mais complexa ou mais onerosa, para os envolvidos, entre duas ou mais formas para a prática de determinado ato. No caso em tela, isto é, conforme as decisões do Tribunal de Justiça (TJSP), mencionadas em momento anterior, os envolvidos são: O Requerente de um lado - O Município de outro lado - E os Munícipes de forma indireta de outro lado. Sabendo-se que é dever de todos zelar do Erário Público ou seja: (O Prefeito do Município de São Paulo e seus auxiliares) os quais respondem pelo erário público do Município, e todo o arcabouço funcional e as pessoas naturais ou pessoas jurídicas de direito privado ou de direito público). Assim, o Município em sua ação fiscalizatória, equivoca-se: quando posicionou o Munícipe na condição de Obrigação por infração que não cometeu, afeta frontalmente uma enorme gama de normas e princípios basilares, dos quais a Administração Pública deve obedecer. Nessa esteira, afeta os direitos do Munícipe, afeta toda Estrutura do Município, fazendo movimentar a Máquina, isto é, todo o aparelhamento do Município. Conduzindo-o e produzindo gastos desnecessários. O grande gargalo está na Hermenêutica aplicada pelo Município de São Paulo, ou seja: $\mathrm{Na}$ interpretação dogmática e na forma fria da literalidade da Lei. Sendo assim, por desconsiderar a análise sistemática que envolve todo arcabouço do Auto de infração e multa (sabendo-se que o ato Administrativo é vinculado e deve prescindir dos requisitos mínimos necessários à sua validação: Para evitar a ocorrência de irregularidades pela falta de propósito negocial ou abuso de forma, situações que desviam da finalidade da Administração Pública. Diante de todo o exposto em síntese apertada só nos resta as considerações finais.

\section{CONSIDERAÇÕES FINAIS}

O desenvolvimento do presente artigo possibilitou em apertada síntese uma incursão histórica a luz do criacionismo com o escopo de analisar e compreender o Instituto da Posse, bem como, o Direito de Propriedade. Nesse ponto foi avaliado qual era o tipo de tratamento conferido a posse e ao direito de propriedade: $E$, as inquietações da manifestação do ser humano nesse tipo de relação. Diante dessa reflexão foi possível avaliar os benefícios e as dificuldades de lidar com esses institutos. Isto permitiu usar da analogia como maneira de dialogar no tempo e através do tempo. De maneira geral 
a bibliografia utilizada, inclusive as teorias que em dado momento parecem não ter nenhum vínculo com o objeto do presente artigo. Manifestam ao menos em abstrato um interesse constante sobre o tema em comento: devido a sua abrangência e seus reflexos em outras searas do conhecimento e do Direito Pátrio. Assim, a condição Sui Generis da posse é de fato importante e socialmente relevante e nesse raciocínio a Jurisprudência dos Tribunais se mantém firme em festejar o Pacto havido entre as partes, impossibilitando qualquer ocorrência que possa afetar os direitos e garantias fundamentais, como premissas basilares do nosso ordenamento Pátrio. Neste contexto foi observado e verificado que: a interdisciplinaridade da matéria ora em questão é fruto dessa ligação umbilical e sui generis da posse. Isto se confirma por meio da doutrina, das leis e pelos trabalhos dos pesquisadores de disciplinas aparentemente díspares. Nessa toada e diante de uma síntese apertada: A bibliografia utilizada genericamente falando, não descaracterizou a complexidade do Tema e muito menos a estrutura de sua pretensão. Sendo assim: satisfatório o alcance dos objetivos gerais e específicos, pontilhados nesse artigo. A Teoria do Criacionismo foi de suma importância, por seu conteúdo histórico, mas pela possibilidade de comparação, ressaltando a importância da aplicabilidade das leis, sobre os olhares da propriedade, da Posse e do Domínio. Dessa maneira a teoria em comento, funcionou como um túnel do tempo ou uma reflexão as origens da posse. Assim possibilitando uma prospecção de valor histórico que possibilitou por analogia: a pretensão de equiparar e dialogar sobre o direito de posse e suas implicações no agir do ser humano. Seja em relação aos tempos de outrora ou em relação aos dias atuais: Ressaltando que não se trata de um confronto entre leis divinas ou leis terrestres, tendo apenas a pretensão de apresentar, ressalvadas as devidas proporções: a verossimilhança e a fumaça do bom direito entre elas. Assim, as teorias do Universo Holográfico; do Big Bang; da Relatividade Geral e Heliocêntrica: Não deixam de ser tão importantes quanto a teoria do criacionismo. Afinal de contas essas teorias são as provas da incansável saga humana que almeja alcançar ou desvendar a origem do universo, seja por uma regra de fé ou científica. Nesse passo, essas teorias são bases confirmatórias de propriedade intelectual ou de direito autoral, assim, sem nenhuma elasticidade, tal direito pode ser classificado e entendido, a depender do caso concreto, como: [Direito Intelectual da Posse, devido a sua 
condição sui generis que alcança tanto o direito imaterial e o direito de propriedade, configurando assim a moldura tríplice dá posse, por abranger um caráter imaterial de prerrogativas morais e por outro contorno, materiais em virtude do direito de propriedade e de outro lado os de ordem patrimoniais]. Nesse ponto o Ordenamento Pátrio, as decisões Jurisprudências dos Tribunais e a Doutrina, compõe todo o arcabouço jurídico e doutrinário para manter o equilíbrio social concernente as pretensões fundadas no direito de propriedade e no direito de posse. Dada a relevância do tema e devido a sua abrangência e sem nenhuma elasticidade pode-se vislumbrar que: Os estabelecimentos de ensino superior poderiam dar maior atenção ao Instituto da Propriedade e da Posse, observando que: tal matéria é a base e estrutura dorsal do direito. Tudo é posse e de certa maneira se construiu a ideia de propriedade, assim, tudo é propriedade, más apenas alguns terão o Domínio. Sabendo-se, que o direito está assentado sobre o tripé: Vida, Liberdade e Patrimônio. Isto resultaria em melhor qualificação técnica, possibilitaria a eficiência dos entes públicos nas suas prestações de serviços, diminuindo assim: a judicialização e harmonizando pacificamente a tríade: Autor; Réu e o Judiciário (Estado Juiz). Neste sentido os meios utilizados para construção desse artigo, permitiram alcançar os objetivos gerais e pontuar a importância do direito de propriedade e do direito de posse, no âmbito social material e imaterial e, no âmbito jurídico. Dessa maneira o Ordenamento Pátrio caminha sobre a proteção de Deus, BEATI POSSIDENTIS (bendita seja a posse).

\section{REFERÊNCIAS}

ALEX, Robert. Teoria de los derechos fundamentales. Madrid: Centro de Estúdios Constitucionales, 1993. p. 277.

ALMEIDA, João Ferreira de. A BíBLIA SAGRADA. Publicado por Alfalit Brasil em cooperação com Alfalit Internacional. inc. Impresso em Suécia: Com permissão da Editora Vida, Reservados todos os direitos. Tradução das Línguas Originais, por João Ferreira de Almeida. Edição Contemporânea Revisada e Aumentada com ajudas adicionais. ano 1996. 
ALVES, Alexandre Ferreira de Assumpção. A pessoa jurídica e os direitos da personalidade. Rio de Janeiro: Renovar, 1998, p. 85.

AQUINO, Felipe. Estado laico ou laicista? Lorena; São Paulo: ed. Cléofas, 2009. Disponível em: https://cleofas.com.br//?s=Estado+laico+ou+laicista. Acesso em 14/01/2019.

BANDEIRA DE MELLO, C. A. Curso de Direito Administrativo. 12ª ed. São Paulo: Malheiros, 2000, p. 748.

BITTAR, Carlos Alberto. Os direitos da personalidade. 4. ed. Rio de Janeiro: Forense Universitária, 2000, p. 127.

BRASIL SENADO FEDERAL. Breves notas introdutórias de Roger Stiefelmann Leal. 2012, $\quad$ p. $53 \quad$ - $57 . \quad$ Disponível em: https://www12.senado.leg.br/ril/edicoes/49/194/ril_v49_n194_p53.pdf. Acesso em: 28 de março de 2019.

BRASIL, Senado Federal. Cretella Júnior, J. Os cânones do direito administrativo. Revista de informação legislativa, v. 25, n. 97. Disponível em: < www.2.senado.leg.br/bdsf/item/id/22 >. Acesso em: 07 de outubro de 2016. p. 5- 52.

BRASIL. Biblioteca. Supremo Tribunal Federal. FREITAS, Augusto Teixeira de. Promptuario das Leis Civis (Instituto Typografhico do Direito, 1876) Rio de Janeiro - RJ. PATRIMÔNIO do SUPREMO TRIBUNAL DE JUSTIÇA (STF) N.12539.9. p. 212, 213, 224.

Disponível

em:< http://sistemas.stf.jus.br/xmlui/handle/123456789/560. Acesso em: 06 de janeiro de 2019.

BRASIL. Câmara dos Deputados. Lei №. 4.132 de 10 de dez. de 1962. Ementa. Que define os casos de desapropriação por interesse social e dispõe sobre sua aplicação. Disponível em: http://www.planalto.gov.br/ccivil_03/leis/L4132.htm. Acesso em: 10/08/2018. 
BRASIL. Código Civil Brasileiro. Instituído pela Lei n. 10.406, de 10 de janeiro de 2002. Vade Mecum Saraiva. obra coletiva da Editora Saraiva, com a colaboração de Livia Céspedes e Fabiana Dias da Rocha. 25aㅡ ed. atual e ampl. São Paulo: Saraiva Educação, 2018.

BRASIL. Código de Defesa do Consumidor. Lei, ㄲo.8.078, de 11 de setembro de 1990. Vade Mecum Saraiva / obra coletiva da Editora Saraiva com a colaboração de Livia Céspedes e Fabiana Dias da Rocha. 25ª ed. atual e ampl. São Paulo: Saraiva Educação, 2018.

BRASIL. Código de Processo Penal. Instituído pelo Decreto-lei n. 3.689, de 3 de outubro de 1941. Vade Mecum Saraiva. obra coletiva da Editora Saraiva, com a colaboração de Livia Céspedes e Fabiana Dias da Rocha. 25aㅗ ed. atual e ampl. - São Paulo: Saraiva Educação, 2018. Art. 65. p. 507.

BRASIL. Código Penal. Instituído pelo Decreto-Lei n. 2.848, de 7 de dezembro de 1940. Vade Mecum Saraiva. obra coletiva da Editora Saraiva, com a colaboração de Livia Céspedes e Fabiana Dias da Rocha. 25ํㅡ ed. atual e ampl. - São Paulo: Saraiva Educação, 2018.

BRASIL. CONSELHO NACIONAL DE JUSTIÇA. Resolução n. 125 de 11 de novembro de 2010. Dispõe sobre a Política Nacional de tratamento adequado dos conflitos de interesses no âmbito do Poder Judiciário e dá outras providências. Política Judiciária Nacional; Conflitos de interesse; meios consensuais; Núcleos Permanentes de Métodos Consensuais de Solução de Conflitos; Treinamento e capacitação [...]. Disponível em: https://atos.cnj.jus.br/atos/detalhar/atos-normativos?documento=156. Acesso em: 15 de jan. 2019.

BRASIL. Constituição Federal da República Federativa do Brasil. Aprovada pela Assembleia Constituinte em 22 de setembro de 1988 e promulgada em 05 de outubro de 1988. Vade Mecum Saraiva. obra coletiva da Editora Saraiva, com a colaboração de Livia Céspedes e Fabiana Dias da Rocha. 25ํㅡㄹ ed. atual e ampl. São Paulo: Saraiva Educação, 2018. 
BRASIL. Constituição Politica do Imperio do Braszil (de 25 de março de 1824). Constituição Política do Império do Brasil, elaborada por um Conselho de Estado e outorgada pelo Imperador D. Pedro I, em 25.03.1824. Manda observar a Constituição Politica do Imperio, oferecida, e jurada por Sua Magestade o Imperador. Disponível em: https://www.planalto.gov.br/ccivil_03/constituicao/constituicao24.htm. Acesso em: 10 de outubro 2019.

BRASIL. Decreto $n^{\circ}$. 54.535, de 30 de outubro de 2001. Diário Oficial da Cidade de São Paulo.31/10/2013, p. 1. Ano 58, nº. 207.

BRASIL. Decreto, 353 de 12 de julho de 1845. Designa os casos em que terá lugar a desapropriação por utilidade publica geral, ou municipal da Corte. Collecção das Leis do Imperio do Brasil. 1845. Tomo 7º, Parte 1ª , Secção 18ª .

BRASIL. Decreto, ㄲo 4.074 de 04 de janeiro de 2002. Regulamenta a Lei, ㄲo 7.802 de 11 de julho de 1989, que dispõe sobre a pesquisa, a experimentação, a produção, a embalagem e rotulagem, o transporte, o armazenamento, a comercialização, a propaganda comercial, a utilização, a importação, a exportação, o destino final dos resíduos e embalagens, o registro, a classificação, o controle, a inspeção e a fiscalização de agrotóxicos, seus componentes e afins, e dá outras providências. Disponível em:_http://www.planalto.gov.br/ccivil_03/decreto/2002/D4074.htm. Acesso em: 05/07/208.

BRASIL. Decreto, №. 50.895, de 1 de outubro de 2009. Aprova o Regulamento do Processo Administrativo Fiscal. Diário Oficial da Cidade de São Paulo. 02/10/2009. p. 1 -3. São Paulo, 54 (184) - 3. Art. 38. Caput. Parágrafo 2º, inciso I, II e parágrafos 3ㅜㅜ, $4 \div$.

BRASIL. Decreto-lei Federal, $\mathrm{n}^{\circ} .3 .365$ de 1941. Ementa. Dispõe sobre desapropriações por utilidade pública. Disponível em: http://www.planalto.gov.br/ccivil_03/decreto-lei/Del3365.htm. Acesso em:10 de jan. 2019. 
BRASIL. DICIONÁRIO AURELIO. Definição de Posse. Retenção ou fruição de uma coisa ou de um direito., Estado de quem possui uma coisa, de quem detém como sua ou tem o gozo dela., Ação ou direito de possuir a título de propriedade., Fortuna, haveres., Capacidade, aptidão., Meios, forças; alcance, tomar posse: meter de posse, dar posse, diz-se de ato pelo qual alguém é investido ou investe outrem num direito, num cargo ou dignidade. Disponível em: https://dicionariodoaurelio.com/posse. Acesso em: 12/08/2018.

BRASIL. Lei Complementar, ํㅜ 140 de 08 de dezembro de 2011. Fixa normas, nos termos dos incisos III, VI e VII do caput e do parágrafo único do art. 23 da Constituição Federal, para a cooperação entre a União, os Estados, o Distrito Federal e os Municípios nas ações administrativas decorrentes do exercício da competência comum relativas à proteção das paisagens naturais notáveis, à proteção do meio ambiente, ao combate à poluição em qualquer de suas formas e à preservação das florestas, da fauna e da flora; e altera a lei oㅡ 6.938, de 31 de agosto de 1981. Disponível em: http://www.planalto.gov.br/ccivil_03/leis/lcp/Lcp140.htm. Acesso em: 15 de janeiro de 2019.

BRASIL. Lei Federal, n. 8.245 de 18 de outubro de 1991. Vade Mecum Saraiva. obra coletiva da Editora Saraiva, com a colaboração de Livia Céspedes e Fabiana Dias da Rocha. $25^{\mathrm{a}}$ ed. atual e ampl. São Paulo: Saraiva Educação, 2018. Dispõe sobre as locações dos imóveis urbanos e os procedimentos a elas pertinentes.

BRASIL. Lei n. 9.610, de 19 de fevereiro de 1998. Dispõe a respectiva Lei. Sobre, Altera, atualiza e consolida a legislação sobre direitos autorais e dá outras

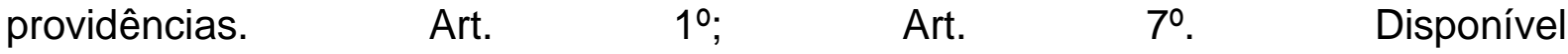
em: _http://www.planalto.gov.br/ccivil_03/leis/L9610.htm. Acesso em: 15 de jan. 2019.

BRASIL. Lei Orgânica do Município de São Paulo. Disponível em: https://www.prefeitura.sp.gov.br/cidade/secretarias/upload/educacao/cme/LOM.pdf. Acesso em: 10/08/2018. 
BRASIL. Lei, $n^{\circ}$. 13.140, de 26 de junho de 2015. Dispõe sobre a mediação entre particulares como meio de solução de controvérsias e sobre a autocomposição de conflitos no âmbito da administração pública; altera a Lei n 9.469, de 10 de julho de 1997, e o Decreto $n^{\circ} 70.235$, de 6 de março de 1972 ; e revoga o $\S 2^{\circ}$ do art. $6^{\circ}$ da Lei $n^{\circ}$ 9.469, de 10 de julho de 1997. Disponível em: http://www.planalto.gov.br/ccivil_03/_ato2015-2018/2015/lei/L13140.htm. Acesso em: 15 de jan. 2019.

BRASIL. Lei, oํ 16, de 12 de agosto de 1934. Faz algumas alterações e edições à Constituição Política do Império, nos termos da Lei d 12 de outubro de 1932. Coleção de Lei do Império do Brasil. 1834, p. 15 vol. 1 (Publicação Original).

BRASIL. Lei, № 9 de setembro de 1826. Marca os casos em que terá que logar a desapropriação da propriedade particular por necessidade, e utilidade pública e as formalidades que devem preceder a mesma desapropriação. Disponível em: http://www.planalto.gov.br/ccivil_03/leis/lim/LIM-9-9-1826.htm. Acesso em: 15 de janeiro de 2019.

BRASIL. Lei, № 9.279, de 14 de maio de 1996. Regula Direitos e Obrigações Relativos à Propriedade Industrial. Vade Mecum Saraiva. obra coletiva da Editora Saraiva, com a colaboração de Livia Céspedes e Fabiana Dias da Rocha. 25ํㅡㄹ ed. atual e ampl. São Paulo: Saraiva Educação, 2018. p. 1685-1699.

BRASIL. Lei, №. 12.115, de 28 de julho de 1.996. Regulamentada pelo Decreto, no 36.646/1996. Revogada pela Lei, №. 13.525/2003. Disponível em: http://legislacao.prefeitura.sp.gov.br/leis/lei-12115-de-28-de-junho-de-1996. Acesso em: 10/08/2018.

BRASIL. Lei, ํo. 12.527, de 18 de novembro de 2011. Lei de Acesso à Informação. Vade Mecum Saraiva / obra coletiva da Editora Saraiva com a colaboração de Livia Céspedes e Fabiana Dias da Rocha. 25a. ed. atual e ampl. São Paulo: Saraiva Educação, 2018. p. 2159-22163. 
BRASIL. Lei, №. 13.474 de 30 de dezembro de 2002. Disponível em: https://www.prefeitura.sp.gov.br/cidade/secretarias/upload/arquivos/secretarias/finan cas/legislacao/Lei-13474-2002.pdf. Acesso em: 11/08/2018.

BRASIL. Lei, nº. 6.938, de 31 de agosto de 1981. Dispõe sobre a Política Nacional do Meio Ambiente, seus fins e mecanismos de formulação e aplicação, e dá outras providências. Vade Mecum Saraiva. obra coletiva da Editora Saraiva, com a colaboração de Livia Céspedes e Fabiana Dias da Rocha. 25a ed. atual e ampl. São Paulo: Saraiva Educação, 2018. Art. 1‥p. 1.410.

BRASIL. Lei, no. 8.078, de 11 de setembro de 1.990. Código do Consumidor. Vade Mecum Saraiva. obra coletiva da Editora Saraiva, com a colaboração de Livia Céspedes e Fabiana Dias da Rocha. 25a ed. atual e ampl. São Paulo: Saraiva Educação, 2018. Art. 1․ Caput. p. 744.

BRASIL. Lei, n. 8.934, de 18 de novembro de 1.994. Dos Atos Pertinentes ao Registro Público de Empresas Mercantis e Atividades Afins. Vade Mecum Saraiva / obra coletiva da Editora Saraiva com a colaboração de Livia Céspedes e Fabiana Dias da Rocha. 25ạ. ed. atual e ampl. São Paulo: Saraiva Educação, 2018. Art. 33. p. 1.649.

BRASIL. Lei, no. 9.605, de 12 de fevereiro de 1.989. Disponível em: http://www.planalto.gov.br/ccivil_03/leis//9605.htm. Acesso em: 15 de jan. 2019.

BRASIL. Lei, no.7.735, de 22 de fevereiro de 1989. Dispõe sobre a extinção de órgão e de entidade autárquica, cria o Instituto Brasileiro do Meio Ambiente e dos Recursos Naturais Renováveis e dá outras providências. Disponível em: http://www.planalto.gov.br/ccivil_03/Leis/L7735.ht… Acesso em: 15 de jan. 2019.

BRASIL. Lei, №.7.797, de 10 de julho de 1989. Cria o Fundo Nacional do Meio Ambiente e dá outras providências. Disponível em: http://www.planalto.gov.br/ccivil_03/Leis/L7797.htm. Acesso em: 15 de jan. 2019.

BRASIL. Lei, №.7.802 de 11 de julho de 1989. Disponível em: http://www.planalto.gov.br/ccivil_03/Leis/L7802.htm. Acesso em: 15 de jan. 2019. 
BRASIL. Município de São Paulo. Decreto, № 36.646, de 18 de dezembro de 1996. Regulamenta a Lei, no 12115, de 28/06/1996. Retificado - Diário Oficial do Município, 241296, p. 1.

BRASIL. Município de São Paulo. Lei, nº 14.223, de 26 de setembro de 2006. Dispõe sobre a ordenação dos elementos que compõem a paisagem urbana do Município de São Paulo. Acesso em: https://leismunicipais.com.br/a/sp/s/sao-paulo/leiordinaria/2006/1422/14223/lei-ordinaria-n-14223-2006-dispoe-sobre-a-ordenacaodos-elementos-que-compoem-a-paisagem-urbana-do-municipio-de-sao-paulo. Disponível em: 10/08/2018.

BRASIL. Município de São Paulo. Lei, № 13.525 de 28 de fevereiro de 2003. (Projeto de Lei, 406/02, da Vereador Myryam Athie - PPS). Dispõe sobre a ordenação de anúncios na paisagem do Município de São Paulo e dá outras providências. Publicado em 01 de março de 2003. Diário Oficial do Município de São Paulo. Disponível em: http://legislacao.prefeitura.sp.gov.br/leis/lei-13525-de-28-de-fevereiro-de2003/detalhe. Acesso em: 10 de jan. 2018.

BRASIL. Novo Código de Processo Civil. Lei, n. 13.105 de 16 de março de 2015. Vade Mecum Saraiva / obra coletiva da Editora Saraiva com a colaboração de Livia Céspedes e Fabiana Dias da Rocha. 25ạ. ed. atual e ampl. São Paulo: Saraiva Educação, 2018.

BRASIL. Planalto. Lei Complementar no 140 de 08 de dezembro de 2011. Vade Mecum Saraiva. obra coletiva da Editora Saraiva, com a colaboração de Livia Céspedes e Fabiana Dias da Rocha. 25a ed. atual e ampl. São Paulo: Saraiva Educação, 2018. Art. 9, Caput, Inciso, I, II [...]. p. 2.179.

BRASIL. Prefeitura do Estado de São Paulo. Decreto n. 54.535 de 30 de out. 2013.

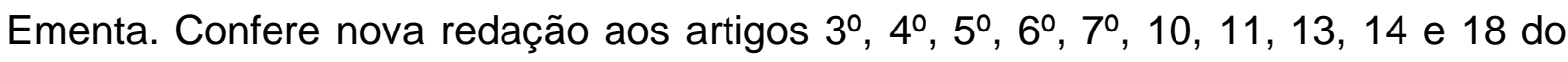
Decreto $n^{\circ}$. 53.799, de 26 de março de 2013, que estabelece o procedimento a ser observado para a desapropriação de bens úteis ou necessários aos interesses da Administração Municipal.

Disponível em: 
$<$ http://legislacao.prefeitura.sp.gov.br/leis/decreto-54535-de-30-de-outubro-de2013 >. Acesso em: 11/08/2018. Outra Fonte. Diário oficial da Cidade de 31/10/2013. p. 1.

BRASIL. Revista da Universidade Federal de Minas Grais (UFMG). v. 19, n. 1 e 2, p. 182-205, dez. 2012.

BRASIL. Revistas da Universidade de São Paulo (USP). Steiner, J. A origem do universo, Estudos Avançados, v. 20, n, 58, p. 231-248, 1 dez. 2006. Disponível em: www.revistas.usp.br/eav/article/view/10192. Acesso em:21/06/2018.

BRASIL. Senado Federal. PORTO, Walter Costa (org.). (Coleção Constituições brasileiras; v. 1). Nogueira, Octaciano 1824 / Octaciano Nogueira. 3. ed. - Brasília: Senado Federal, Subsecretaria de Edições Técnicas, 2012. p.12, 21-22. ISBN: 97885-7018-424-5.

Disponível em:_https://www2.senado.leg.br/bdsf/bitstream/handle/id/137569/Constituicoes_Bras ileiras_v1_1824.pdf. Acesso em: 14. jan. 2019.

BRASIL. Superior Tribunal de Justiça (STJ). RECURSO ESPECIAL. AÇÃO DE MANUTENÇÃO DE POSSE. DIREITO DE RETENÇÃO POR ACESSÃO E BENFEITORIAS. CONTRATO DE COMODATO MODAL. CLÁUSULAS CONTRATUAIS. VALIDADE. (...) 3. A atribuição de encargo ao comodatário, consistente na construção de casa de alvenaria, a fim de evitar a "favelização" do local, não desnatura o contrato de comodato modal. 4. Recurso especial não provido". (STJ, REsp 1316895/SP Rel. Ministra Nancy Andrighi, j. em 11.06.2013.) (g/n) Número Registro: 2011/0301020-4 Processo Eletrônico REsp. 1.316.895/SP, Números de Origem: 336136201082605645640120100033619682010 990103170229. Disponível em: http://stj.jus.br Acesso em: 17 de maio de 2019.

BRASIL. Tribunal de Justiça do Estado de São Paulo (TJSP). Ação fundada em extinção de comodato verbal, com prazo indeterminado Presença dos requisitos previstos no artigo 927, incisos I a IV, do CPC Posse direta exercida pela ré que não anula a indireta exercida pela autora - Notificação premonitória visando extinguir o 
comodato A permanência da ré no imóvel, após ser notificada para desocupá-lo, configura esbulho possessório Ré que não comprovou, tal como lhe competia, a teor do art. 333, II, do Código de Processo Civil, ocupar o imóvel na condição de locatária Pagamento de prestações do financiamento do imóvel que não descaracteriza o comodato Ação de reintegração de posse procedente Recurso improvido." (Ap. n. 0000703-17.2011.8.26.0269, Rel. Des. Plinio Novaes de Andrade Júnior, 24ạ Câmara de Direito Privado, j. em 1.10.2015.) Disponível em: http://www.tjsp.jus.br. Acesso em 17 de maio de 2019.

BRASIL. Tribunal de Justiça do Estado de São Paulo (TJSP). Decisões do Tribunal (Sob o Registro: 2017.0000692055), ACORDÃO. Apelação $n^{\circ}$. 100729977.2015.8.26.0004. AÇÃO DE REINTEGRAÇÃO DE POSSE. Imóvel urbano. Ação fundada em extinção de comodato verbal, com prazo indeterminado (...). Disponível em: http://www.tjsp.jus.br. Acesso em: 17 de maio de 2019.

BRASIL. Tribunal de Justiça do Estado de São Paulo (TJSP). Reintegração de posse. Contexto probatório dos autos que autoriza o acolhimento da pretensão vestibular. Demonstrada a existência de comodato verbal e modal relativamente ao imóvel em questão. Sentença mantida. Recurso desprovido." (Ap. n. 000010466.2012.8.26.0003, Rel. Des. Luis Carlos de Barros, 20ª Câmara de Direito Privado, j. em 14.3.2016.). ACORDÃO Registrado pelo №. 2016.0000200032. Disponível em http://www.tjsp.jus.br. Acesso em:17 de maio de 2019.

BRASIL. Tribunal de Justiça do Estado de São Paulo. Decisões do Tribunal (Sob o Registro: 2018.0000081077, ACORDÃO, Apelação no. 1040212-28.2016.8.26.0053, multa administrativa destituída de natureza propter rem); também foi verificado ser incabível a solidariedade disposta no Art. 32, da "Lei Cidade Limpa" sob o Registro: 2018.0000608504, ACORDÃO, Apelação Cível/Reexame Necessário/Multas e demais Sansões no 0100869-31.2008.8.26.0053). Disponível em: http://www.tjsp.jus.br. Acesso em:17. mai. 2019.

CAMPINHO, Sérgio. $O$ direito de empresa à luz do novo Código Civil. 4. ed. Rio de Janeiro: Renovar, 2004, p. 354. 
CARVALHO DE MENDONÇA, J. X. Tratado de direito comercial brasileiro. Atualizado por Ricardo Negrão. Campinas: Bookseller, 2000, v. 2, tomo 1, p. 176 177.

CARVALHO, Raquel Melo Urbano de. Curso de Direito Administrativo. Salvador: Jus Podivm, 2008. p. 1066.

CARVALHOSA, Modesto. Comentários ao Código Civil. São Paulo: Saraiva, 2003, v. 13, p. 731.

CERQUEIRA, João da Gama. Tratado da propriedade industrial. Rio de Janeiro: Forense, 1946, v. 1, p. 73.

COELHO, Fábio Ulhoa. Curso de direito comercial. 6. ed. São Paulo: Saraiva, 2002, v. 1 , p. 177.

COUTO, Felipe Rabelo. A QUESTÃO DO ACRÉ E A SOLUÇÃO NACIONAL DE RUI BARBOSA. Revista Veredas da História, [online]: v.8, n. 1, 2015. p. 55- 85, ISSN $1982-4238$.

Disponível

em:

http://www.seer.veredasdahistoria.com.br/ojs2.4.8/index.php/veredasdahistoria/articl e/view/162/153 . Acesso em: 12 de janeiro de 2019.

DE CUPIS, Adriano. Os direitos da personalidade. Tradução de Adriano Vera Jardim e Antônio Miguel Caeiro. Lisboa: Livraria Morais, 1961, p. 178 -179.

DE CUPIS, Adriano. Os direitos da personalidade. Tradução de Adriano Vera Jardim e Antônio Miguel Caeiro. Lisboa: Livraria Morais, 1961, p. 17.

FERRARA JUNIOR, Francesco. Teoría jurídica de la hacienda mercantil. Traducción por José Maria Navas. Madrid: Revista de Derecho Privado, 1950, p. 180.

FERRARA, Francesco. Trattato di diritto civile italiano. Roma: Athenaeum, 1921, p. 666. 
FERREIRA, Aurélio Buarque de Holanda (1996), "definir é explicar o significado de alguma coisa, indicar o seu verdadeiro sentido."

FREITAS, Augusto Teixeira de. Consolidação das leis civis / Augusto Teixeira de Freitas; prefácio de Ruy Rosado de Aguiar. Ed. Fac-sim. - Brasília: Senado Federal, Conselho Editorial, 2003. 2. V (Coleção história do direito brasileiro. Direito Civil). p. 86 ,

Disponível em:

https://ww2.stj.jus.br/publicacaoinstitucional/index.php/colecaodc/article/view/85 >. Acesso em: 18 de outubro de 2018.

FREYTAG'S, Gustav. Tecnique of de Drama And Exposition of Dramatic Composition And Art. By Dr. Gustav Freytag authorized translation fron the sixth German Edition by Elias J. Mac Ewan, M.A. Third Edition. Chicago Scott, Foresman and 1900.

Disponível

em:

$<$ https://archive.org/details/freytagstechniqu00freyuoft > Acesso em: 03/11/2018. p. 101,112 - 114.

GUIMARÃES. 2005.

JAPIASSÚ, Hilton e MARCONDES, Danilo. Dicionário Básico de Filosofia. 5.ed. Rio de Janeiro: Zahar, 2008.

JUSTEN FILHO, Marçal. Curso de Direito Administrativo. 11. ed. São Paulo: Revista dos Tribunais, 2015. p. 626-627.

KELSEN, Hans. Teoria pura do direito. [tradução João Baptista Machado]. 6 ed. São Paulo: Martins Fontes, 1998. (Ensino Superior). Disponível em: https://portalconservador.com/livros/Hans-Kelsen-Teoria-Pura-do-Direito.pdf Acesso em: 10 de jan. 2018.

MAMEDE, Gladston. Direito empresarial brasileiro. São Paulo: Atlas, 2004, v. 1, p. $110-111$. 
MARLON, Tomazette. Curso de Direito Empresarial. Teoria Geral e Direito Societário., 5ํe edição, Volume 1 Livro Digital São Paulo editora Atlas S.A 2013. Edição digital, p. 155-162. Edição expressa, p. 126-133. ISBN: 9788522476251 - e ISBN 9788522476893.

MARLON, Tomazette. Curso de direito empresarial: Teoria geral e direito societário, v. 1 / Marlon tomazette. - 8. ed. rev. e atual. - São Paulo: Atlas, 2017.

MIRANDA, Jorge. Manual de direito constitucional. 3. ed. Coimbra: Coimbra, 2000. p. 307.

MIRANDA, Pontes de. Tratado de direito privado. Atualizado por Vilson Rodrigues Alves. Campinas: Bookseller, 2000, v. XV, p. 111;

MIRANDA, Pontes. Tratado de direito privado, v 17, p. 4.

MONTESQUIEU, Charles de Secundat, Baron de. 1689-1755. O Espirito das Leis / Montesquieu. apresentação Renato Janine Ribeiro. Tradução Cristina Murachco. São Paulo: Martins Fontes, 1996. (Paidéia). ISBN 85-336-0553-6. 2ª tiragem fevereiro 2000. p. 19.

NEGRÃO, Ricardo. Manual de direito comercial e de empresa. 9. ed. São Paulo: Saraiva, 2012, v. 1, p. 222 - 223.

NUNES JÚNIOR, Vidal Serrano. Publicidade comercial: proteção e limites na Constituição de 1988. São Paulo: Juarez de Oliveira, 2001. p. 21 - 23.

NUNES JÙNIOR, Vital Serrano e SERRANO, Yolanda Alves Pinto. Código de Defesa do Consumidor interpretado. São Paulo: Saraiva, 2003, p. 214.

QUEIROZ LIMA, Eusébio de. Conceito de Domínio e Posse/Segundo Código Civil Brasileiro. Lente substituto da $1^{\text {a }}$ Secção da Faculdade Livre de Direito do Rio de Janeiro: Supremo Tribunal Federal Patrimônio n. 14-424-5. p. 1 - 97. 


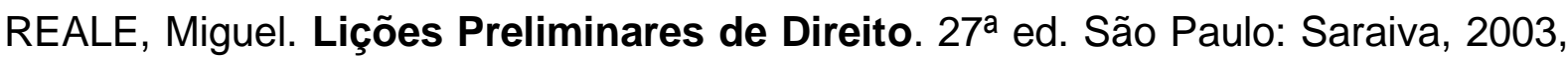
p. 37.

SÁ BARRETO, F. C. DE; VAZ, L. P. R.; FRANCO, G. A. P. O universo vivo. Revista da Universidade Federal de Minas Gerais, v. 19, n. 1 e 2, p. 182-205, 12 dez. 2012. Disponível em: https://periodicos.ufmg.br/index.php/revistadaufmg/article/view/2718. Acesso em: 21/01/2018.

SOARES. Evanna. A norma jurídica em Kelsen. Concepção de sanção na norma primária e na norma secundária. Revista Jus Navigandi. ISSN 1518-4862, Terezina, ano 7, n. 59, 1 out. 2002. Disponível em: < https://jus.com.br/artigos/3269 >. Acesso em: 23 jul. 2018.

SOUZA, Daniel Adensohn. Proteção ao nome empresarial no Brasil. São Paulo: Saraiva, 2012, p. 78.

STEINER, João E. A origem das coisas sempre foi uma preocupação central da humanidade; [...]. In: (rev, usp). A Origem do Universo. Estudos Avançados, v. 20, n, 58, p. 231-248, 1 dez. 2006. Disponível em: www.revistas.usp.br/eav/article/view/10192. Acesso em:21/06/2018.

TALBOT, Michael. A Teoria do Universo Holográfico: em apertada síntese nos informa que o universo é um gigantesco holograma. In: Tradução, Marques, Maria De Fátima S.M. O Universo Holográfico. Título Original "The Holographic Universe". Ed. Best Seller. 1991.

Disponível em:

Https://Contraeducacao.Files.Wordpress.Com/2012/09/Livro-O-Universo-

Holografico-Michael-Talbot.Pdf . Acesso em: 21/06/2018.

VALERI, Giuseppe. Manuale di diritto commerciale. Firenze: Casa Editrice Dottore Carlo Cya, 1950, v. 2, p. 2425.

ZAVASCKI, Teori Albino. A tutela da posse na Constituição e no Novo Código Civil. Revista Brasileira de Direito Constitucional, n. 5, p 50-61, jan /jun. 2005. Disponível 
em:_http://bdjur.stj.jus.br/jspui/bitstream/2011/6723/A_Tutela_da_Posse_na_Constit ui\%C3\%A7\%C3\%A3opdf . Acesso em: 15 outubro 2018. p. 26.

ZAVASCKI, Teori Albino. A tutela da posse na Constituição e no Novo Código Civil. Revista Brasileira de Direito Constitucional, n. 5, p 50-61, jan /jun. 2005. Disponível em:_https://bdjur.stj.jus.br/jspui/handle/2011/6723. Acesso em: 23/11/2018. p. $1 ; 2$.

Enviado: Janeiro, 2020.

Aprovado: Outubro, 2020. 